\title{
The Multifaceted Bacterial Cysteine Desulfurases: From Metabolism to Pathogenesis
}

\author{
Mayashree Das, Arshiya Dewan (), Somnath Shee and Amit Singh *
}

Citation: Das, M.; Dewan, A.; Shee, S.; Singh, A. The Multifaceted Bacterial Cysteine Desulfurases: From Metabolism to Pathogenesis. Antioxidants 2021, 10, 997. https:// doi.org/10.3390/antiox10070997

Academic Editor: Bruce Morgan

Received: 8 April 2021

Accepted: 6 May 2021

Published: 23 June 2021

Publisher's Note: MDPI stays neutral with regard to jurisdictional claims in published maps and institutional affiliations.

Copyright: (c) 2021 by the authors. Licensee MDPI, Basel, Switzerland. This article is an open access article distributed under the terms and conditions of the Creative Commons Attribution (CC BY) license (https:/ / creativecommons.org/licenses/by/ $4.0 /)$.
Centre for Infectious Disease Research, Department of Microbiology and Cell Biology, Indian Institute of Science, Bangalore 560012, India; mayashreedas@iisc.ac.in (M.D.); arshiyadewan@alum.iisc.ac.in (A.D.); somenathshee@iisc.ac.in (S.S.)

* Correspondence: asingh@iisc.ac.in; Tel.: +91-8022932604

\begin{abstract}
Living cells have developed a relay system to efficiently transfer sulfur (S) from cysteine to various thio-cofactors (iron-sulfur (Fe-S) clusters, thiamine, molybdopterin, lipoic acid, and biotin) and thiolated tRNA. The presence of such a transit route involves multiple protein components that allow the flux of $S$ to be precisely regulated as a function of environmental cues to avoid the unnecessary accumulation of toxic concentrations of soluble sulfide $\left(\mathrm{S}^{2-}\right)$. The first enzyme in this relay system is cysteine desulfurase (CSD). CSD catalyzes the release of sulfane S from L-cysteine by converting it to L-alanine by forming an enzyme-linked persulfide intermediate on its conserved cysteine residue. The persulfide $S$ is then transferred to diverse acceptor proteins for its incorporation into the thio-cofactors. The thio-cofactor binding-proteins participate in essential and diverse cellular processes, including DNA repair, respiration, intermediary metabolism, gene regulation, and redox sensing. Additionally, CSD modulates pathogenesis, antibiotic susceptibility, metabolism, and survival of several pathogenic microbes within their hosts. In this review, we aim to comprehensively illustrate the impact of CSD on bacterial core metabolic processes and its requirement to combat redox stresses and antibiotics. Targeting CSD in human pathogens can be a potential therapy for better treatment outcomes.
\end{abstract}

Keywords: cysteine desulfurase (CSD); Fe-S cluster; redox; thio-cofactors; ROS

\section{Introduction}

Sulfur (S) is an essential element for life [1]. Biomolecules contain S predominantly in amino acids such as methionine and cysteine or thio-cofactors and thio-nucleosides. Cysteine can be accessed via inorganic sources (sulfate $\left(\mathrm{SO}_{4}{ }^{2-}\right)$, sulfide $\left(\mathrm{S}^{2-}\right)$, thiosulfate $\left(\mathrm{S}_{2} \mathrm{O}_{3}{ }^{2-}\right)$, and sulfonate $\left.\left(\mathrm{R}_{-} \mathrm{SO}_{3}{ }^{-}\right)\right)$, reverse transsulfuration pathway, glutathione, and cysteine import [2]. A multi-protein S-relay system then utilizes intracellular cysteine to synthesize thio-cofactors and thio-nucleosides [1]. Since excess of soluble-S ( $S^{2-} /$ cysteine) induces metabolic paralysis, the S-relay pathway imparts significant evolutionary advantages by providing an alternative route of $S$ transfer to essential thio-cofactor binding proteins without allowing soluble $S$ to reach toxic levels [3].

$S$ is mobilized from cysteine to diverse biomolecules via cysteine desulfurase (CSD). Cysteine desulfurases (CSDs: plural) are ubiquitous and highly conserved PLP (pyridoxal$5^{\prime}$-phosphate)-dependent enzymes [4]. They decompose L-cysteine to L-alanine while releasing sulfane $S\left(S^{0}\right)$ via the formation of an enzyme-linked persulfide (R-SSH(R)) intermediate on its conserved cysteine residue [5]. The persulfide $S$ formed is then utilized to generate wide-ranging S-containing cofactors involved in various biosynthetic pathways [4-6]. This S-trafficking enzyme was first discovered in Azotobacter vinelandii as part of a gene cluster involved in nitrogen fixation (nif) [7]. This CSD named NifS catalyzes the formation of Fe-S clusters specifically in the nitrogenase enzyme complex by providing inorganic sulfide [7]. Following this, a homolog of NifS was characterized for its role in 
Fe-S cluster biogenesis of housekeeping proteins and named IscS in A. vinelandii [8]. Subsequently, several CSDs across various kingdoms were characterized and termed homologs of NifS, IscS, and SufS [9-11]. CSD is pivotal in Fe-S cluster assembly, tRNA modification, and biosynthesis of thiamine, biotin, lipoic acid, molybdopterin, nicotinamide adenine dinucleotide (NAD), and branched-chain amino acids [4,5]. In addition to its function in primary metabolism, CSD expressed by soil-dwelling Nocardia and Streptomyces spp. is involved in donating $\mathrm{S}$ to form thiotetronate-ring of an antimicrobial metabolite, thiolactomycin (TLM) [12-14]. Studies have shown anti-mycobacterial, anti-malarial, and anti-trypanosomal activities of TLM [15-18]. The maintenance of intracellular redox homeostasis is imperative for the survival of pathogens [19]. Within their host, pathogens face an onslaught of oxidative and nitrosative stress [19]. Remarkably, CSD has been shown to protect bacteria from oxidative stress generated within the phagocytes and by antibiotics, plus chemical agents such as potassium tellurite or oxidants (menadione, plumbagin, and cumene hydroperoxide) [20-24]. In sum, CSD contributes to not only housekeeping functions but also mediates stress-defense and pathogenicity.

The first review on CSD was published in 2002 by Mihara et al. [4]. In the following two decades, there has been tremendous progress on understanding the mechanism and function of CSD in diverse organisms, including major human pathogens. This paper aims to comprehensively summarize and underline CSD as a pivotal node linking its essentiality in diverse biochemical pathways with evasion from oxidative damage induced by the host immune pressures to antibiotics and exogenous chemicals. Therefore, CSD exhibits all criteria for a potential drug target and demands the discovery of inhibitor molecules to combat the rise in antimicrobial resistance (AMR).

\section{Classification and Distribution of Cysteine Desulfurases}

\subsection{Classification}

CSD (EC 2.8.1.7) belongs to the class of sulfur-transferases and catalyzes the transfer of $\mathrm{S}$ from substrate L-cysteine to various partner carrier proteins to synthesize S-containing cofactors and thio-nucleotides [4-6]. The first discovered CSD was NifS (Nitrogen-Fixation) from A. vinelandii $[11,25]$. NifS is involved in the maturation of the metallocluster (FeS) of the nitrogenase complex in nitrogen-fixing bacteria, certain microaerophiles, and non-nitrogen-fixing anaerobes $[5,7,26]$. Subsequently, enzymes belonging to this family (IscS, SufS, CsdA, YrvO, and DndA) were discovered in organisms across bacterial species [4,27-30]. These CSD homologs differ at the level of primary amino acid sequence, local structural organization, and enzyme kinetics, based on which CSDs are classified into two categories (Table 1) [4,5]. Members of Class I CSDs are similar to NifS and IscS, whereas Class II includes SufS-like and cysteine sulfinate desulfinase A (CsdA)-like proteins (Figure 1A) $[4,5]$. Sequence alignment of CSDs delineates two primary differences-a 12-residue sequence insertion after the active site cysteine in Class I CSDs (Figure 1B). In contrast, Class II members contain a distinct sequence insertion near the PLP-coordinating Lysine [4-6]. The consensus sequences around the conserved cysteine also act as an identifier -SSGSACTS- in Class I, whereas -RXGHHCA- in Class II [5]. Furthermore, the catalytic loop containing the nucleophilic cysteine is extended and structurally more flexible in Class I enzymes than Class II enzymes [4,6]. Additionally, the participation of Class I and Class II proteins in distinct pathways is influenced by the interacting protein partners. For example, the IscS (Type I) enzyme participates in Fe-S cluster biogenesis upon interaction with the $\mathrm{S}$ acceptor (IscU), whereas its participation in (thio-)tRNA biosynthesis is mediated via interaction with TusA and Thil [31-33]. The multiple interacting partners of the Class I CSDs are likely due to the flexible catalytic loop; however, NifS and Bacillus subtilis NifZ interact with their specific partners NifU and ThiI, respectively $[34,35]$. Unlike Type I CSDs, Type II CSDs such as SufS [36,37] and CsdA [38] interact with specific S acceptor proteins SufE or SufU and CsdE, respectively, for Fe-S cluster biogenesis and in the generation of cyclic threonylcarbamoyladenosine (ct ${ }^{6} \mathrm{~A}$ ) at 37 th position (for CsdA). $\mathrm{N}^{6} \mathrm{ct}^{6} \mathrm{~A}$ and its derivatives in tRNA are responsible for ANN codon usage [39]. Due to structurally defined 
shorter catalytic loop, Type II CSDs' activity is exclusively dependent on its interaction with specific partner proteins. Another class of CSD has been reported in cyanobacteria Synechocystis PCC 6714. This PLP-dependent L-cyst(e)ine C-S-lyase (C-DES) is a monomer and lacks a conserved cysteine residue at the active site, explaining its insensitivity to alkylating agents $[40,41]$. It generates sulfide, ammonia, and pyruvate from cysteine/cystine instead of alanine and sulfane $S[40,41]$. The crystal structure and in vitro studies suggest the formation of a product-cysteine-persulfide in C-DES processed reaction compared to enzyme-linked persulfide generated by the other classes of CSD [40,41]. C-DES has been shown to participate in the Fe-S cluster biogenesis of ferredoxin $[40,41]$.

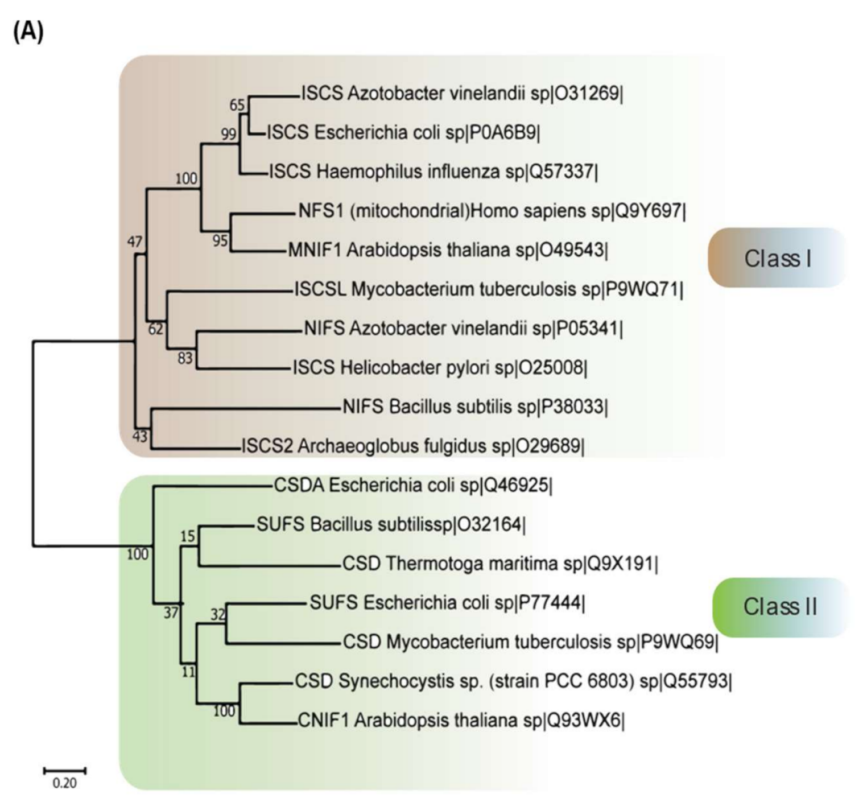

(B)

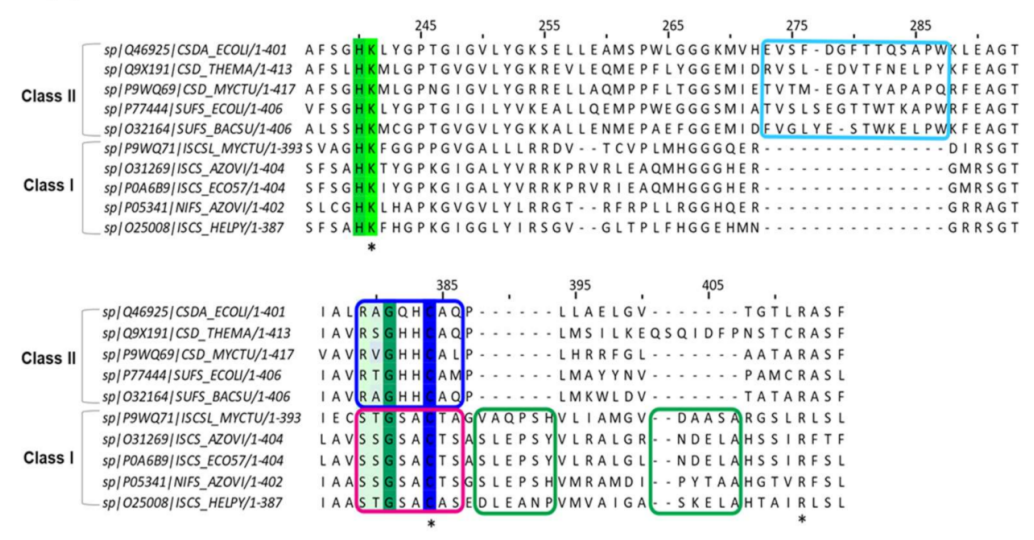

Figure 1. Phylogenetic analysis of CSD enzymes of organisms from different domains. (A) Maximum likelihood phylogenetic reconstruction of 17 CSD homologs from organisms spanning throughout three domains: Eukarya, Bacteria, and Archaea. Evolutionary analysis performed in MEGA X [42]. The CSD homologs are seen to cluster into two main branches, which can be determined as Class I and II. This tree has a maximum log-likelihood of -13398.96 . The scale bar shows genetic distance. Bootstrap values (500 replicates) shown next to the branches. (B) Multiple sequence alignment of different bacterial CSD homologs. CSDs are indicated as UniProt ID. The green-highlighted lysine (K)-residue is the highly conserved PLP-coordinating residue, while the cyan box highlights the sequence insertion acquired by the Class II CSDs. The green boxes focus on the sequence insertion inherent to the Class I CSDs, whereas the blue and pink box features the differences in the sequences adjacent to the active site cysteine. Conserved lysine, cysteine and arginine residue are indicated by "**". 
Table 1. Classification of CSDs based on primary amino acid sequences.

\begin{tabular}{|c|c|c|c|c|c|c|}
\hline Enzyme & Organism & Class & Identifier I $^{\mathbf{a}}$ & Identifier II $^{\mathbf{b}}$ & Identifier III $^{c}$ & \\
\hline NifS & Azotobacter vinelandii & I & SSGSACTS & & $\begin{array}{l}\text { Insertion near } \\
\text { conserved cysteine }\end{array}$ & \\
\hline IscS & Azotobacter vinelandii & I & SSGSACTS & & $\begin{array}{c}\text { Insertion near } \\
\text { conserved cysteine }\end{array}$ & \\
\hline IscS & Helicobacter pylori & I & STGSACAS & & $\begin{array}{c}\text { Insertion near } \\
\text { conserved cysteine }\end{array}$ & Dimer \\
\hline IscS & Escherichia coli & I & SSGSACTS & & $\begin{array}{c}\text { Insertion near } \\
\text { conserved cysteine }\end{array}$ & \\
\hline SufS/CsdB & Escherichia coli & II & RTGHHCA & $\begin{array}{l}\text { Insertion near } \\
\text { conserved lysine }\end{array}$ & & \\
\hline CsdA & Escherichia coli & II & RAGQHCA & $\begin{array}{l}\text { Insertion near } \\
\text { conserved lysine }\end{array}$ & & \\
\hline SufS & Bacillus subtilis & II & RAGHHCA & $\begin{array}{l}\text { Insertion near } \\
\text { conserved lysine }\end{array}$ & & \\
\hline SufS/CSD & $\begin{array}{l}\text { Mycobacterium } \\
\text { tuberculosis }\end{array}$ & II & RVGHHCA & $\begin{array}{l}\text { Insertion near } \\
\text { conserved lysine }\end{array}$ & & \\
\hline IscS & $\begin{array}{l}\text { Mycobacterium } \\
\text { tuberculosis }\end{array}$ & I & STGSACTA & & $\begin{array}{c}\text { Insertion near } \\
\text { conserved cysteine }\end{array}$ & \\
\hline CSD & Thermotoga maritima & II & RSGHHCA & $\begin{array}{l}\text { Insertion near } \\
\text { conserved lysine }\end{array}$ & & \\
\hline C-DES * & Synechocystis PCC 6714 & & & & & Monomer \\
\hline
\end{tabular}

a, b, c: CSDs from different organisms can be classified into two main categories based on their sequence identifiers: (I) patch of amino acid sequence neighboring the active site cysteine; (II) presence/absence of amino acid-stretch insertion near the conserved lysine residue coordinating PLP; and (III) 12-amino acid-residue insertion adjacent to the active site cysteine. ${ }^{*}$ C-DES is a novel PLP-dependent L-cyst(e)ine C-S-lyase, which converts cysteine to pyruvate, ammonia, and sulfide.

\subsection{Distribution}

CSDs exist in all three domains of life. The genes encoding for NifS, IscS, SufS, and CsdA were discovered within the Fe-S cluster biosynthetic machinery-NIF, ISC, and SUF (SUF-like) [43]. The genes involved in the Fe-S cluster biosynthesis are arranged in operons in most bacteria, while there are exceptions of dispersed genes (Figure 2) [43,44]. The Fe-S biogenesis systems in Escherichia coli and A. vinelandii are the most extensively studied. E. coli contains both the ISC and the SUF systems, while $A$. vinelandii contains the NIF and ISC systems [45,46]. Comparison of bacterial genomes revealed that microorganisms differ in the number and type of operons they utilize. For instance, most Gram-positive bacteria, archaea, and cyanobacteria contain only a suf operon and display specific differences from the E. coli counterpart. Compared to E. coli, the SUF system in Gram-positive bacteria codes for an IscU-like scaffold protein in place of SufU and lacks S-transfer protein SufE [45]. In addition to SufS, the model Gram-positive bacterium Bacillus subtilis harbor three other CSDs: NifZ, NifS, and YrvO. Moreover, the human pathogen Mycobacterium tuberculosis $(M t b)$ consists of only a suf operon (sufRBDCSUT) with two additional genes, sufR a transcriptional regulator $[47,48]$ and sufT involved in Fe-S cluster maturation $[49,50]$, in addition to a single gene of the isc operon, iscS [51,52]. 


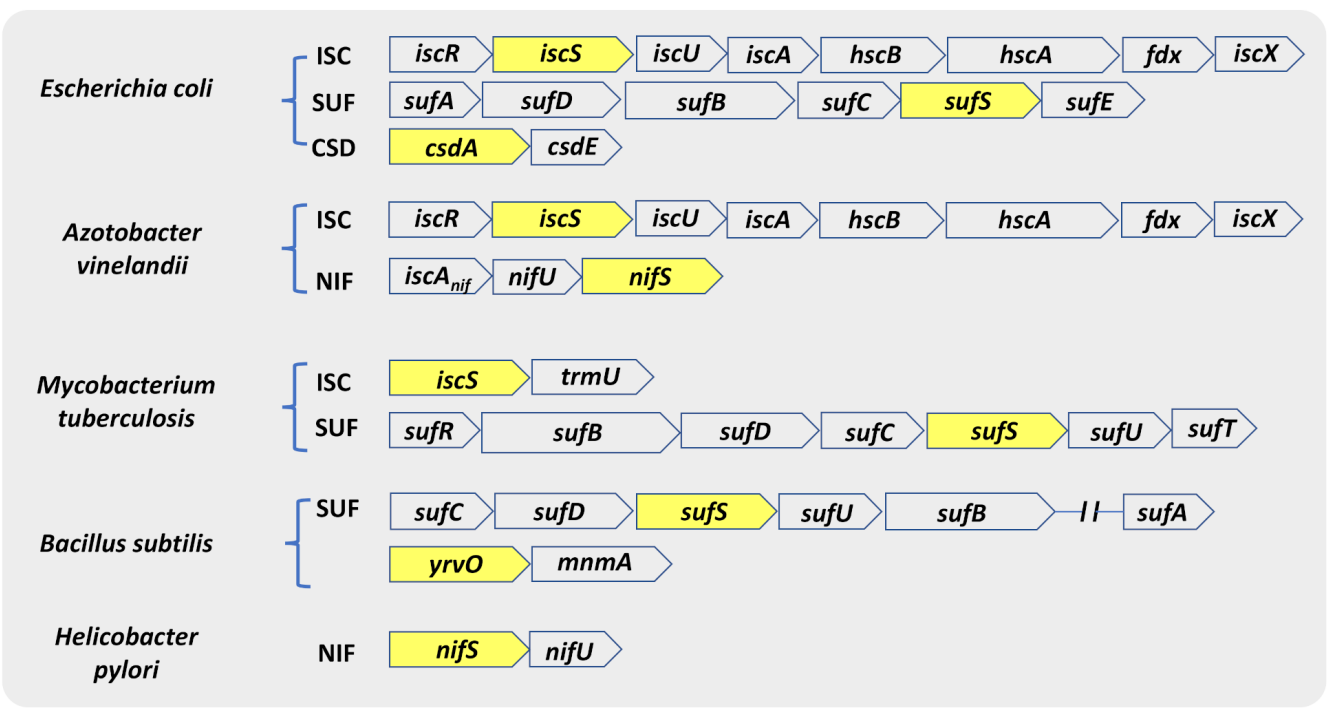

Figure 2. Genetic arrangement of ORFs coding for different classes of CSD. CSD genes in various organisms mostly remain associated with the genetic loci encoding Fe-S cluster biogenesis machinery (ISC, SUF, and NIF). The genetic map also shows that different bacterial species have evolved to harbor different combinations of Fe-S cluster biogenesis machinery. Genes indicated inside yellow boxes are the respective CSD of that operon.

\section{Structure and Reaction Mechanism of Cysteine Desulfurase}

\subsection{Structure}

The crystal structure of both Type I (Thermotoga maritima NifS, Mtb IscS, and E. coli IscS) $[51,53,54]$ and Type II CSDs (E. coli CsdB/SufS, B. subtilis SufS, and Synechocystis sp. PCC 6803 SufS) [55-57] have been solved. Based on amino acid sequence and three-dimensional structural analysis, CSDs are grouped into the fold-Type I family of PLP-dependent enzymes and belong to the aminotransferase class $\mathrm{V}$ sub-family (Figure 3A) $[6,58,59]$. These enzymes form a homodimer with a structural distinction into a small $\mathrm{N}$ - and a large C-terminal domain. Each monomer contains a PLP cofactor, bound covalently to a conserved lysine residue (Lys206 in E. coli IscS) in the active site pocket near the dimer interface. The secondary structures building the CSD comprise both $\alpha$-helices and $\beta$-sheets, with $\alpha$-helices making the major fraction (40.1\% in E. coli IscS) [54]. A distinct loop extending between the small and large domain contains catalytic cysteine residue (Cys328 in E. coli IscS) and forms one side of the entrance-channel for the substrate towards the CSD active site. As discussed above, in most Type I enzymes, this catalytic loop is extended (Figure 3B). The catalytic cysteine is located far away from active-site pocket ( $>1.7 \mathrm{~nm}$ in E. coli IscS), suggesting that the steps of desulfuration are sequential and not cooperative [54]. However, the loop, being structurally disordered, is highly flexible and undergoes a large conformational change in every catalytic cycle $[4,6,60]$. This catalytic loop movement is critical since a mutation adjacent to the loop (Ala 327Val in Salmonella IscS) probably restricts this movement by $\beta$-branching of Val residue. This inhibits IscS catalysis and thereby induces thiamine auxotrophy and decreased level of thionucleosides [61]. On the other hand, the catalytic loop is shorter and more rigid for the Type II enzymes and located near the active site ( $\sim 0.7 \mathrm{~nm}$ in E. coli SufS) (Figure 3C) [6,60]. Type II enzymes also harbor a characteristic insertion-sequence near the PLP-binding lysine residue, which is absent in the IscS-like enzymes. This region forms a $\beta$-hairpin structure that likely imparts structural rigidity to the catalytic loop $[54,60]$. These structural properties can answer specific characteristics of Type II enzymes: (i) decreased length and flexibility of catalytic loop coerce CSD to depend on partner proteins for attaining favorable reaction kinetics; and (ii) mutations in CSD that alter the topology of this $\beta$-hairpin structure lead to the weak interaction between CSD and interacting partner protein, suggesting that $\beta$-hairpin structure probably evolved to improve interaction with the partner proteins [62]. 


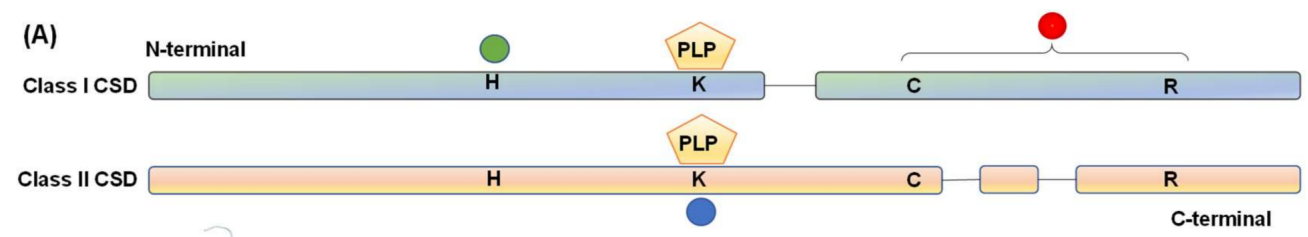

(B)

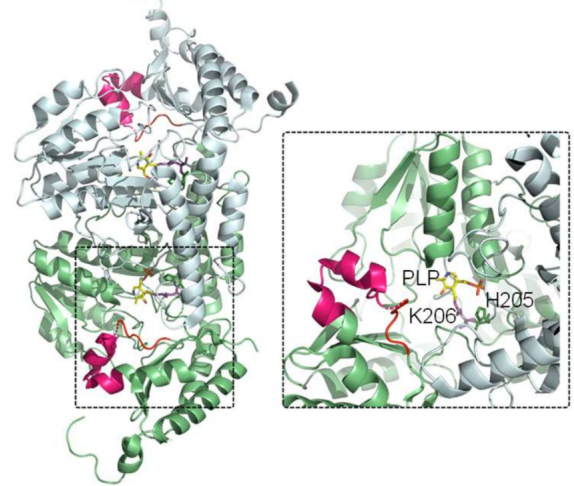

(C)

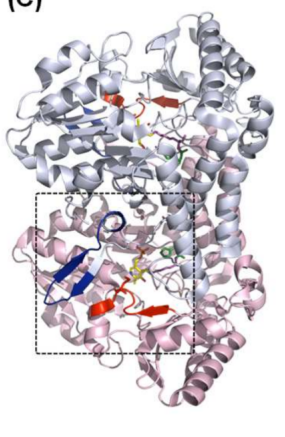

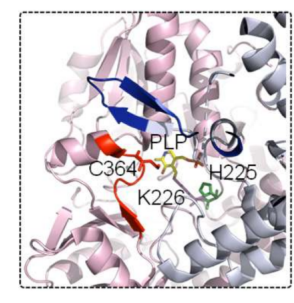

Figure 3. Diagram representing the domain architecture of CSD from Classes I and II. (A) The green circle indicates conserved histidine residue involved in acid-base catalysis and interaction with PLP-L-cysteine. Conserved cysteine and arginine residues are in the catalytic loop region, as indicated by the red circle. PLP is pyridoxal- $5^{\prime}$-phosphate is covalently bound to conserved lysine residue (blue circle). Comparison of the three-dimensional structures of the (B) Class I (E. coli IscS, PDB ID- 3LVM) and (C) Class II (E. coli SufS, PDB ID- 6UY5) CSD enzymes highlights the differences between the two classes. Conserved histidine, lysine, and catalytic cysteine residues are shown as stick representation in forest green, magenta, and red. The PLP moiety is shown in yellow. Identifiers I-III are highlighted in red, blue, and hot pink, respectively.

\subsection{Reaction Mechanism}

CSD performs the desulfuration of its substrate L-cysteine, forming L-alanine and $\mathrm{S}^{0}$ or $\mathrm{S}^{2-}$ (under reducing conditions). The aldehyde group of the PLP cofactor allows the formation of an imine with a free amino group, and the pyrimidine ring structure acts as an electron-sink which are crucial interactions for the reaction to occur [62,63]. CSD's reaction cascade can be divided into two sequential stages: (i) formation of the enzymelinked cysteine persulfide (R-S-S-SH); and (ii) the transfer of the persulfide to respective S-acceptor proteins $[4,26,57]$.

Persulfide formation on the enzyme occurs through the formation of following intermediate states (Figure 4): (i) transition of the internal Lys-aldimine (resting state) to the external Cys-aldimine (Schiff base), which requires sequential proton transfers and via formation of a geminal aldimine; (ii) the external aldimine formed creates an electronic coupling of the imine and pyrimidine ring of the PLP, generating a conjugated pi-electron withdrawal system, which aids in proton abstraction from substrate cysteine by a basic residue (probably His104 in E. coli IscS [6,26,64]) acting as a general base; (iii) it is followed with the active site Cys-thiol acting as a general acid and donates a proton to form Cys-PLP quinonoid adduct; (iv) this paves the way for the reaction for the nucleophilic attack on the substrate-thiol by the conserved cysteine, resulting in the formation of the enzymelinked persulfide intermediate and an alanine-enamine PLP adduct; (v) general acid/base reactions lead to formation of Ala-ketimine and then Ala-aldimine, probably mediated by CSD's His-residue; and (vi) finally, through reverse order of substrate binding steps, the product alanine is released with restoration of Lys-PLP internal aldimine [6]. 


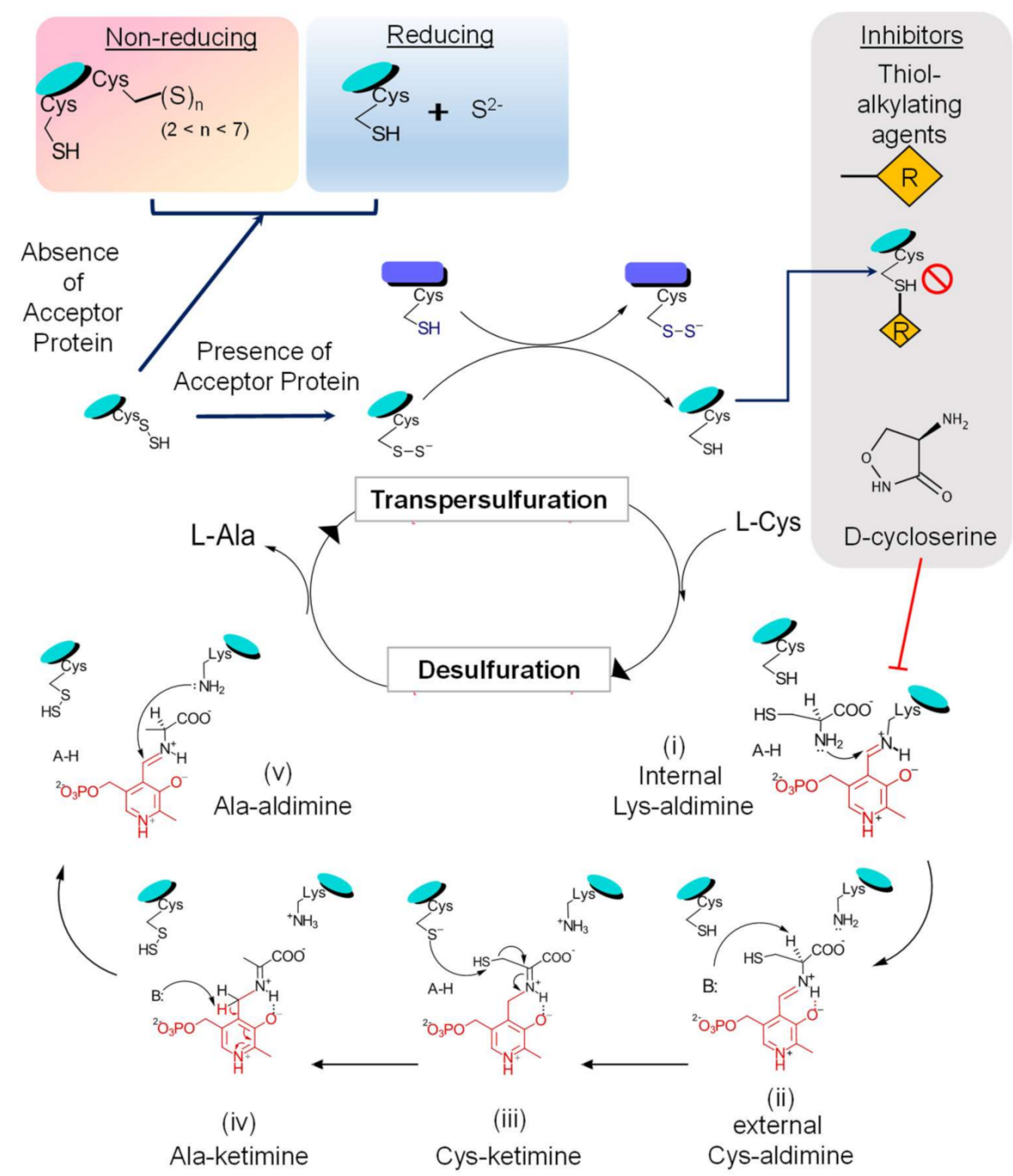

Figure 4. Schematic representation of the CSD reaction mechanism. The enzymatic activity of CSD can be divided into two phases: firstly, desulfuration of substrate L-cysteine and formation of the enzyme-bound persulfide intermediate, followed by the transfer of persulfide to its acceptor proteins, transpersulfuration. During the first phase of the reaction, the covalently bound cofactor-PLP acts as an electron sink and aids in the nucleophilic attack and the concomitant S-abstraction. This reaction proceeds via the formation of several reactive intermediate steps. The outcome of transpersulfuration can depend on the adjacent redox environment and the availability of S-acceptor proteins. On interaction with S-acceptor proteins, there is a transfer of the CSD-bound persulfide to the reactive thiol of an active site cysteine residue in the acceptor protein. However, in the absence of acceptors, the persulfide can get released as $\mathrm{S}^{2-} / \mathrm{H}_{2} \mathrm{~S}$ under reducing conditions or form polysulfide species $\mathrm{S}_{\mathrm{n}(2<\mathrm{n}<7)}$ on an adjacent free thiol under non-reducing conditions. Furthermore, the activity of CSD can be inhibited by thiol-alkylating agents (such as N-ethylmaleimide, iodoacetamide) by irreversibly modifying the thiol group of the active cysteine residue. CSDs, being PLP-dependent enzymes, are inhibited by molecules that covalently interact with the PLP-moiety forming irreversible protein-inhibitor complexes (for example, D- or L-cycloserine).

The next step involves the transfer of terminal $S$ to cysteine residues in acceptor proteins via persulfide intermediates. This is proposed to occur either by a nucleophilic attack on $S$ acceptor by the enzyme's persulfide $S$ or vice versa [65]. The kinetic analysis demonstrates a ping-pong mechanism where product alanine is released first, followed by transpersulfuration to partner proteins [37]. However, in the absence of acceptor proteins, the persulfide can have two different fates based on the pertaining redox environment: (i) persulfide is released as $\mathrm{S}^{2-} / \mathrm{H}_{2} \mathrm{~S}$ under reducing conditions; or (ii) enzyme linked- 
polysulfide species $\mathrm{S}_{\mathrm{n}} ;(2<\mathrm{n}<7)$ are formed on an adjacent free thiol under non-reducing conditions [66]. This process of persulfide transfer to the acceptor proteins is a significant advantage as it ensures the safe mobilization of $S$ in a nontoxic form (sulfides) [3,67-69]. The mechanism of persulfide transfer and type of interacting S-acceptor partners differ among the two classes as described above. In vitro and in vivo studies in E. coli and B. subtilis have highlighted the phenomenon of enhanced desulfurase activity of SufS (Type II) in a tight complex-formation with SufE/SufU (by 30-50 fold [70]), which is not in the case for IscS/IscU interactions $[37,70]$. SufE also interacts with the scaffold component SufB of the $\mathrm{SufB}_{2} \mathrm{C}_{2} / \mathrm{SufBC}_{2} \mathrm{D}$ complex, which further enhances the activity of SufS by accelerating the transpersulfuration process by $\sim 100$ fold [70]. This requirement for partner proteins by CSD for optimal activity suggests that CSD catalysis can be targeted by inhibiting the enzyme directly and by impeding the availability or function of S-acceptor proteins. Contrary to the specific interaction of SufS-SufE, SufS-SufU, and CsdA-CsdE, IscS can interact with multiple S-carriers like IscU, ThiI, and TusA. However, the requirement of partner/acceptor proteins for IscS expressed by the human pathogen $M t b$, is not properly understood because $M t b$ contains only the CSD IscS and lacks other components of the ISC system. Despite this, $M t b$ IscS physically interacts and assembles Fe-S cluster into $M t b$ Fe-S proteins such as WhiB3, aconitase (Acn), and succinate dehydrogenase (SdhB). [51,71]. Therefore, the following questions need investigation to understand $M t b$ IscS activity comprehensively:

(i) What is the mechanism of IscS mediated S-relay in $M t b$ ?

(ii) What scaffold protein participates in this process since IscS do not physically interact with Mtb SufU [51]?

(iii) Is IscS alone sufficient to build Fe-S clusters?

(iv) Does IscS contribute to stress tolerance and pathogenesis in $M t b$ ?

\section{CSD Controls Basal Metabolism by Mobilizing S from Cysteine to Diverse Cellular Pathways}

Several studies indicate that IscS and CsdA contribute to sustain housekeeping function by participating in $\mathrm{Fe}-\mathrm{S}$ biogenesis, thiamine or molybdopterin biosynthesis, and tRNA modification, as described in detail below (Figure 5). In contrast, SufS activity generally restricts to $\mathrm{Fe}-\mathrm{S}$ cluster biogenesis under stress conditions such as oxidative stress, nitrosative stress, and Fe-limitation $[1,5,6]$.

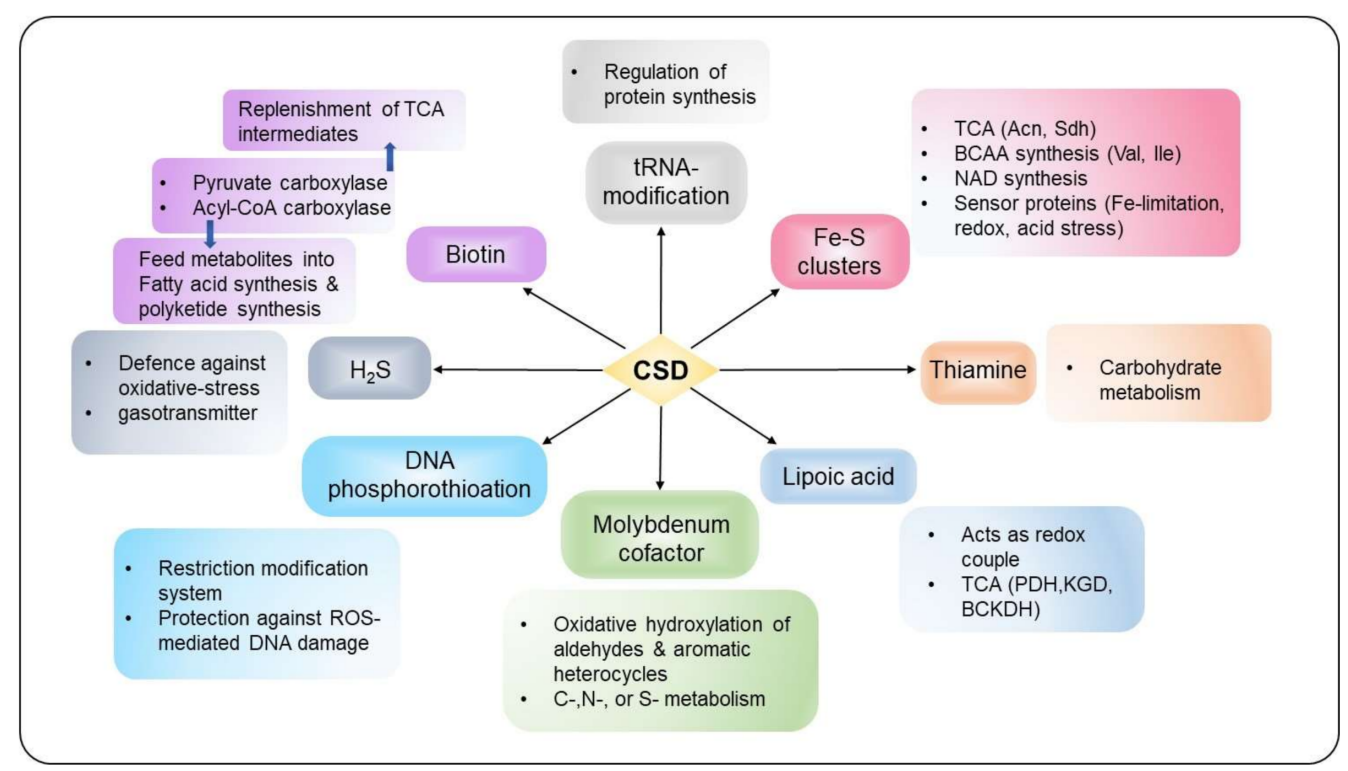

Figure 5. The interconnected network of S-transfer and incorporation into different thio-cofactors and tRNA. CSDs act as a pivotal point between diverse physiological functions, including cellular metabolism, stress response and protection, regulation of gene expression, and virulence. 


\subsection{Fe-S Cluster Assembly}

Fe-S clusters are susceptible to oxidation by molecular oxygen $\left(\mathrm{O}_{2}\right)$ and its reactive intermediates (reactive oxygen species (ROS): hydrogen peroxide $\left(\mathrm{H}_{2} \mathrm{O}_{2}\right)$ and superoxide $\left.\left(\mathrm{O}_{2}{ }^{\bullet-}\right)\right)$, which leads to enzyme-inactivation and disruption of cellular physiology. More specifically, $\mathrm{Fe}^{2+}$ leached from oxidatively damaged Fe-S clusters can trigger the Fenton reaction to generate highly oxidative hydroxyl radicals $\left({ }^{\circ} \mathrm{OH}\right)$, which oxidizes biomolecules at near diffusion-limited rates [44,72]. In addition to this, free $\mathrm{S}$ overload gives rise to toxic polysulfides inside cells [3]. Therefore, to abate deleterious consequences of free $\mathrm{Fe}$ and $\mathrm{S}$, organisms have evolutionarily acquired multicomponent systems for calibrating $\mathrm{Fe}-\mathrm{S}$ cluster biogenesis $[43,44,72]$. The regulation and biogenesis of Fe-S clusters have been extensively reviewed, and readers are encouraged to refer to these reviews $[43,73,74]$. Briefly, Fe-S cluster biogenesis encompasses two key steps: (i) assembly of the Fe-S cluster on the scaffold protein; and (ii) Fe-S cluster trafficking from scaffolds to the respective apoprotein targets. The starting point in Fe-S cluster biogenesis is the acquisition of the elemental components-Fe and S, where cysteine acts as the S source. The protein(s) involved in donating Fe for Fe-S cluster biogenesis remains elusive and needs further research. Subsequently, Fe-S clusters are assembled on the scaffold protein(s) via interaction with $\mathrm{S}$ and Fe donating protein complexes. Finally, the Fe-S clusters are catered to apoproteins with the help of carrier proteins. E. coli ISC system comprises IscR (a transcriptional regulator), IscS (a CSD), IscU (scaffold protein), IscA (an A-type carrier protein), HscB (a DnaJ-like co-chaperone), HscA (a DnaK -like chaperone), Fdx (a ferredoxin), and IscX [75]. The SUF system expresses SufR (a transcriptional regulator), SufS (a CSD), SufE/SufU (enhances SufS activity), SufBCD (scaffold complex), SufA (an A-type carrier protein), and SufT (accessory protein for Fe-S cluster maturation) [49]. The NIF system comprises the cysteine desulfurase NifS and the scaffold protein NifU [11].

The significant contribution of CSD is towards the formation of the Fe-S clusters, which act as cofactors to multiple enzymes. The tricarboxylic acid (TCA) cycle enzymes such as Acn and succinate dehydrogenase are Fe-S cluster-containing proteins [43]. Additionally, the auxotrophy of $E$. coli iscS mutant observed for nicotinic acid, isoleucine, and valine is consistent with the presence of Fe-S cluster on enzymes involved in their biosynthesis [76]. For instance, the precursor of NAD, quinolinic acid, is synthesized by a Fe-S cluster proteinquinolinate synthase A, whereas another Fe-S protein, dihydroxy acid dehydratase, is involved in the biosynthetic pathways of isoleucine and valine [4]. Fe-S cluster proteins also function as sensors (FNR, SoxR, IscR, SufR, WhiBs, etc.) to environmental cues that include gases $\left(\mathrm{O}_{2}\right.$ and nitic oxide $\left.(\mathrm{NO})\right)$, Fe-starvation, ROS, reactive nitrogen intermediates (RNI), and redox-active compounds, which are relayed downstream for the regulation of gene expression and stress tolerance [77,78].

In E. coli and $M t b$, the deletion of iscS reduced growth and lower activity of Fe-S cluster-dependent enzymes (2-50\% of wild-type) [51,76]. Disruption of iscS is not lethal under standard growing conditions, indicating that alternate CSD-SufS could compensate for the loss of iscS in E. coli and $M t b$. Consistent with this, overexpression of SufS restores active growth and enzymatic activity of Fe-S cluster proteins in the IscS mutant of E. coli [79]. The overlapping role of CSD-sufS and iscS is evident by the inability of $E$. coli to survive upon disruption of both the genes [79]. Taken together, these genetic studies demonstrate that CSDs are indispensable for bacterial metabolism and growth.

\subsection{RNA Modification (Thiolation)}

Thio-modifications of transfer RNAs (tRNA) such as 2-thiouridine $\left(\mathrm{s}^{2} \mathrm{U}\right), 4$-thiouridine $\left(\mathrm{s}^{4} \mathrm{U}\right), 2$-thiocytidine $\left(\mathrm{s}^{2} \mathrm{C}\right), 2$-methylthioadenosine $\left(\mathrm{ms}^{2} \mathrm{~A}\right)$, and 2-thiouridothymidine $\left(\mathrm{s}^{2} \mathrm{~T} 54\right)$ are commonly observed across kingdom $[80,81]$. These thio-modifications are on seven tRNA positions: $\left(5^{\prime}-8,9,32,33,34,37\right.$, and 54-3'). Except for thiolated adenines, thionucleosides are mostly formed by replacing the keto-oxygen of the nucleotide base with $\mathrm{S}[9,65,82-85]$. Importantly, the positions at which thio-modifications occur are crucial for tRNA function and topology. Modification on the anticodon stem-loop aids in translational 
accuracy, whereas modifications at the T-loop and D-loop maintain structural stability and serve as a recognition motif for the tRNA aminoacyl synthetase and tRNA-modifying enzymes [80]. Remarkably, the $s^{4} U 8$ tRNA-modification positioned at the acceptor-arm and D-arm junction acts as a near-UV light photosensor and is highly conserved among bacteria [32]. Mechanistically, near-UV light crosslinks s ${ }^{4} U$ with cytidine 13, which induces structural disorder, halts aminoacylation, and impedes translation to signal activation of stringent response in bacteria [32]. Interestingly, hypoxia-induced persistence of $\mathrm{My}$ cobacterium bovis BCG is associated with fluctuations in the levels of modified tRNA and reduction in translation efficiency [86].

Generally, IscS provides $S$ for thio-modifications, except $\mathrm{s}^{2} \mathrm{U}$ modification in $B$. subtilis, where YrvO functions as a CSD $[80,87]$. After $\mathrm{S}$ release by CSD, diverse S-carrier proteins facilitate S- transfer to the modification enzymes. The $\mathrm{s}^{4} \mathrm{U}$ modification involves ThiI protein that contains the PP-loop motif (ATP- binding) and activates the C4 atom of tRNA at U8 via adenylated intermediate. The activated tRNA is next thiolated by the ThiI persulfide derived from the action of IscS [88-91]. Contrary to this, $\mathrm{s}^{2} \mathrm{U}$ modification at the wobble position 34 is tailored by the enzyme MnmA (also known as TrmU), with IscS as the $\mathrm{S}$ donor and the TusABCDE system working as the $\mathrm{S}$ transfer mediators $[81,89]$. Intriguingly, $M t b t r m U$ is proposed to be in an operon with iscS (the only gene of the ISC component in Mtb) [51]. The significance of such operonic arrangement on $M t b$ pathogenesis is unknown and needs to be elucidated to understand the effect of CSD on $M t b$ tRNA levels. Similar to ThiI, MnmA also consists of a PP-loop domain required for the activation of the $\mathrm{C} 2$ atom of $\mathrm{U} 34$ by adenylation. On the other hand, the $\mathrm{s}^{2} \mathrm{C} 32$ modification requires the involvement of a [4Fe-4S] cluster containing protein TtcA in which the Fe-S cluster is sufficed by the IscS-IscU system $[65,92,93]$. The formation of methylthio-derivatives ( $\mathrm{ms}^{2} \mathrm{~A} 37$ ) is catalyzed by methylthiotransferases MiaB and MtaB, both belonging to the radical S-adenosyl-L-methionine (SAM) superfamily, which requires Fe-S clusters for activity [9,83-85]. Hence, the pathways for the synthesis of thiolated tRNA can be segregated based on their dependence on Fe-S cluster-containing proteins [80].

Direct evidence of the involvement of the CSD IscS in tRNA thiolation is shown in Salmonella enterica serovar Typhimurium, where a strain defective in IscS function exhibited reduced levels of all five thiolated nucleosides present in tRNA [61]. Another study on E. coli IscS showed downregulation of two enzymes from the pyrimidine salvage pathway; namely, uridine phosphorylase and cytidine deaminase in the IscS deleted strain, suggesting diminished nucleotide metabolism and, therefore, reduced tRNA-thio-modifications [94]. Additionally, in vitro studies have shown the involvement of CSDs in the incorporation of selenium (Se) into Se containing proteins and tRNA modifications [95,96]. Indeed, E. coli iscS deleted strain were inept in synthesizing 5methylaminomethyl-2-selenouridine in the wobble position of glutamate, lysine, glutaminetRNA, and suffered a reduction in the levels of selenium-containing enzyme formate dehydrogenase $\mathrm{H}(\mathrm{FdhH})$ [96]. In sum, CSD has a dual function in S and Se mobilization.

\subsection{Lipoic Acid Synthesis}

Lipoic acid is an essential organosulfur cofactor for enzymes carrying out oxidative and one-carbon metabolism [97,98]. Lipoate remains covalently attached to the E2 subunit of these complexes through an amide linkage at a conserved $\mathrm{N}$-terminal lysine residue [97-99]. In E. coli, lipoate synthesis is carried out by two reactions: (i) transferring an octanoyl group from octanoyl acyl carrier protein (octanoyl-ACP) to the apoprotein catalyzed by LipB (octanoyl transferase); and (ii) insertion of two $\mathrm{S}$ atoms at the $\mathrm{C} 6$ and C8 positions of octanoyl chain forming the dithiolane ring of lipoate by LipA (lipoate synthase) $[97,98,100]$. Additionally, cells can acquire free lipoate by scavenging, which is mediated by the enzyme lipoate-protein ligase A, LplA by a two-step ATP-dependent reaction to form protein conjugated lipoate. LipA belongs to the radical SAM -superfamily proteins harboring two $[4 \mathrm{Fe}-4 \mathrm{~S}]^{+}$clusters, where one of the clusters is coordinated with $\mathrm{CX}_{4} \mathrm{CX}_{2} \mathrm{C}$ motif, common to all radical SAM enzymes. The second Fe-S cluster is coor- 
dinated by the cysteines of $\mathrm{CX}_{4} \mathrm{CX}_{5} \mathrm{C}$ motif, found only in lipoyl synthases $[98,100,101]$. Lipoate synthesis proceeds through an extraordinary self-sacrifice reaction step where $\mathrm{S}$ is derived from an auxiliary [4Fe-4S] cluster of LipA, which gets degraded after a single catalytic turnover [101,102]. CSD (IscS), NfuA, and IscU (Fe-S biogenesis and repair pathway proteins) efficiently reconstitute these clusters with non-rate-limiting kinetics and prime LipA for the next round of catalysis [101-103]. Therefore, CSD is essential for lipoate biogenesis.

The lipolyated enzymes are pyruvate dehydrogenase (PDH), $\alpha$-ketoglutarate dehydrogenase (KGD), branched-chain keto acid dehydrogenase (BCKDH), acetoin dehydrogenase, and glycine cleavage system $[97,98,104]$. PDH and KGD participate in central carbon metabolism, while BCKDH functions to degrade branched-chain amino acids to generate branched-chain coenzyme A (BC-CoA), which can feed into the TCA cycle or anabolized for branched-chain fatty acid synthesis $[98,99]$. Interestingly, clinical data from patients with multi-drug resistant tuberculosis suggest an upregulation of the Mtb lipB [105]. Deletion of dlaT (the E2 of PDH and PNR/P) had a pronounced effect on $M t b$ 's growth in a standard medium in vitro, sensitized $M t b$ to RNI, and attenuated $M t b$ in the mouse [106]. Additionally, species-specific DlaT inhibitors selectively killed non-replicating $M t b$ [107]. Deletion of E3 subunit of PDH that completes the catalytic cycle of E2 also leads to a severe defect in bacterial growth inside the host [108].

\subsection{Biotin Biogenesis}

Biotin (vitamin B7) is an essential micronutrient required for amino acid metabolism, fatty acid biosynthesis, and replenishment of TCA cycle intermediates [109]. The known biotin-dependent enzymes, such as pyruvate carboxylase and acyl-CoA carboxylases (ACCs), utilize biotin-cofactor to transfer carbon dioxide between metabolites in carboxylation, decarboxylation, and trans-carboxylation reactions [109]. Mtb employs the ACCs to convert substrates such as acetyl-CoA, propionyl-CoA, and butyryl-CoA into intermediates for fatty acid and polyketide biosynthesis, generating an array of structurally distinct lipids such as mycolic acid and multi-methyl branched fatty acids [110]. These complex lipids are known to determine the virulence and pathogenesis of $M t b$ [111].

The task of biotinylation of target proteins is performed by biotin protein ligase enzymes (BPL) encoded by birA $[109,112]$. The process of biotin biosynthesis is discussed in detail elsewhere $[100,112,113]$. Briefly, the biogenesis can be differentiated into two stages: (i) synthesis of precursor compound pimelate thioester (pimeloyl-ACP); and (ii) conversion of pimeloyl-ACP to biotin requires the activities of four conserved enzymes, namely 7-keto8-aminopelargonic acid synthase (KAPAS, bioF), 7,8-diaminopelargonic acid synthase (DAPAS, bioA), dethiobiotin synthase (DTBS, bioD), and biotin synthase (BS, bioB) [109,112-115]. Lastly, the insertion of the $\mathrm{S}$ moiety at the $\mathrm{C} 6$ and $\mathrm{C} 9$ positions of dethiobiotin (DTB) intermediate generates a thiophane ring of biotin. BS, similar to MiaAB and LipA, is categorized as a member of the radical SAM superfamily, which utilizes SAM for radical formation [109,115-117]. BS purified from E. coli, works as a homodimer harboring a [4Fe-4S $]^{2+, 1+}$ cluster and a $[2 \mathrm{Fe}-2 \mathrm{~S}]^{2+}$ cluster $[109,113]$. Studies have shown that $[4 \mathrm{Fe}-4 \mathrm{~S}]^{2+, 1+}$ cluster donates an electron to mediate reductive cleavage of SAM to generate $5^{\prime}$-deoxyadenosyl radical and methionine $[109,113,116]$. The radical then activates the $\mathrm{C}-\mathrm{H}$ bonds at $\mathrm{C} 9$ and C6 of DTB by extracting a proton each; hence, two SAM moieties are required for the first half-reaction. Recent biochemical and biophysical experiments suggest that the $[2 \mathrm{Fe}-2 \mathrm{~S}]^{2+}$ cluster serves as a sacrificial $\mathrm{S}$ donor, following which the cluster is damaged and needs Fe-S cluster reconstitution machinery for preparing BS for another round of catalysis [113,118]. Indeed, CSD (NifS/IscS) is capable of stimulating enzymatic activity of BioB (in vitro) by providing $\mathrm{S}$ for its Fe-S cofactor generation, thus highlighting the role of CSD in biotin-homeostasis [119]. Under pathophysiological conditions, knockdown of the BPL encoding gene in $M t b$ resulted in rapid killing in both acute and chronic infection of mice, highlighting the importance of biotin in Mtb survival inside the host [120]. 


\subsection{Thiamine Synthesis}

Vitamin B1 (thiamine pyrophosphate (TPP)) is a cofactor for enzymes involved in the biosynthesis of branched-chain amino acids and carbohydrate metabolism [121]. TPP is formed from two precursor heterocyclic compounds, 4-amino-5-hydroxymethyl-2methylpyrimidine pyrophosphate (HMP-PP) and 4-methyl-5-( $\beta$-hydroxymethyl) thiazole phosphate (THZ-P), which are synthesized through independent pathways $[116,117]$. The thiazole phosphate intermediate is generated from tyrosine, cysteine, and 1-deoxy-Dxylulose-5-phosphate, through the involvement of at least six gene products (ThiFSGH, ThiI, and ThiJ) [116,122-124]. Mass spectrometric data has shown that ThiS and ThiF co-purify, and ThiS gets post-translationally modified at the carboxy terminus to a thiocarboxylate (ThiS-COSH), which acts as primary S source to thiazole [125]. The IscS mutants are auxotrophic for thiamine and nicotinic acid [76]. The phenotype could be recovered by supplementation with the thiamine precursor 5-hydroxyethyl-4-methyl-thiazole, signifying the requirement of IscS as a S-donor for thiazole biosynthesis [76,121,122,126,127]. IscS procures the $\mathrm{S}$ from L-cysteine, which is relayed on to ThiI (a rhodanese family protein), which further aids in thiolation of activated ThiS (acyladenylated) [128]. The influence of IscS on thiamine biosynthesis could also be mediated through a Fe-S cluster containing radical SAM superfamily enzyme $\mathrm{ThiH}$, which is a tyrosine lyase that acts on the last step of thiazole synthesis $[122,123]$. Therefore, TPP synthesis is intricately connected with CSD activity. However, thiamine auxotrophy is absent under anaerobic conditions [76]. This can be due to either: (i) a decreased requirement of TPP using enzymes during anoxia; or (ii) Fe-S cluster of ThiH can be more sensitive to $\mathrm{O}_{2} /$ ROS-mediated damage. This remains unclear and needs further investigation.

\subsection{Molybdopterin Synthesis}

Molybdopterin (MPT) cofactor (Moco) is constituted of mono-nuclear molybdenum covalently linked to a dithiolene moiety of the tricyclic pterin backbone [129,130]. Enzymes harboring Moco can be classified into three families based on the Moco derivative inserted: (i) xanthine oxidase $(\mathrm{XO}$ ) family; (ii) sulfite oxidase (SO) family; and (iii) dimethyl sulfoxide (DMSO) reductase family [130]. The Xanthine oxidase family performs reactions involving oxidative hydroxylation of aldehydes and aromatic heterocycles that requires $\mathrm{C}-\mathrm{H}$ bond cleavage. Enzymes such as dissimilatory nitrate reductase, formate dehydrogenase, and biotin-S-oxide reductase belong to the DMSO reductase family and function in C, N, or $S$ metabolism [131]. In most organisms studied to date, Moco synthesis is mediated by a conserved biosynthetic pathway that can be segregated into three stages: (i) generation of the cyclic pyranopterin monophosphate (cPMP); (ii) introduction of two $S$ atoms into cPMP forming MPT; and (iii) molybdate insertion to form Moco [132]. The process initiates with the formation of cPMP from 5'-GTP mediated by the enzymes MoaA and MoaC; MoaA contains two [4Fe-4S] clusters marking an influence of Fe-S cluster availability on Moco synthesis [132]. In the consequent step, MPT synthase (MoaD-MoaE) converts cPMP to $\mathrm{MPT}$, via the formation of thiocarboxylate on the C-terminus of MoaD. Here, MoaD acts as the final S donor, which, in turn, derives S from CSD [132]. In E. coli, IscS is demonstrated to physically interact with MoeB and MoaD (the MPT synthase) using surface plasmon resonance analysis [133]. The same study also reports the stimulation of IscS activity due to MoeB and MoaD interaction. Indeed, decreased sulfuration levels of MoaD were observed in $i s c S$ but not sufS or $c s d A$ deleted E. coli strains, demonstrating that IscS is the primary S-donating enzyme to Moco synthesis [133].

\subsection{Hydrogen Sulfide Production}

Hydrogen sulfide $\left(\mathrm{H}_{2} \mathrm{~S}\right)$, attributed as a gasotransmitter, modulates physiological pathways such as inflammation, angiogenesis, cancer biology, and oxidative stress defense [134-136]. The chemical characteristic of $\mathrm{H}_{2} \mathrm{~S}$, along with several studies, suggest that it can influence the basal cellular redox physiology via scavenging ROS and RNI, reacting with metal centers, interact with protein cysteine thiols generating persulfide, 
modulating cellular respiration, and antibiotic tolerance [135-137]. In addition to the evolutionarily conserved transsulfuration pathway and 3-mercaptopyruvate sulfurtransferase (3-MST) enzyme, CSD catalyzes the synthesis of $\mathrm{H}_{2} \mathrm{~S}$ and alanine under reducing conditions [138]. Moreover, a recent study in E. coli has shown that the cysteine desulfurase IscS and not 3-MST, is responsible for $\mathrm{H}_{2} \mathrm{~S}$-production under reducing and anaerobic growth conditions [138]. Indeed, the E. coli iscS mutant strain exhibited reduced $\mathrm{H}_{2} \mathrm{~S}$ levels under anaerobiosis and impaired growth, which was fully restored when treated with an $\mathrm{H}_{2} \mathrm{~S}$ donor $\left(\mathrm{Na}_{2} \mathrm{~S}\right.$ : sodium sulfide). In sum, the findings suggest that $\mathrm{H}_{2} \mathrm{~S}$ generated by IscS activity is a function of the redox state of the bacterial cytoplasm and environmental $\mathrm{O}_{2}$. Another study in pathogen Mycoplasma pneumonia identified CSD HapE to be responsible for the generation of $\mathrm{H}_{2} \mathrm{~S}$, which acts as a virulence factor by potentiating hemolysis [139]. Whether a similar $\mathrm{H}_{2} \mathrm{~S}$-mediated defense mechanism is exploited by other human pathogens such as Salmonella or $\mathrm{Mtb}$ remains unanswered and needs to be examined. In sum, CSD contributes towards producing the gaseous molecule $\mathrm{H}_{2} \mathrm{~S}$ and, thereby, likely impacts bacterial pathogenesis, stress-defense, and antibiotic response.

\subsection{DNA Phosphorothioation}

Phosphorothioate (PT) modification of the DNA sugar-phosphate backbone involves replacing nonbridging oxygen atom in phosphate-moiety by S [140]. PT-modification is governed by two systems- DndABCDE or SspABCD machineries where DndA/IscS and SspA are respective CSDs (Type I) [140,141]. Microbes have evolved this epigenetic modification to protect themselves from methylation-based Restriction Modification (RM) systems and phage-invasion [142]. However, additional functions have been recently attributed to CSD-mediated PT modification. The PT-deleted bacterial strains suffer from increased intracellular ROS accumulation and ROS-mediated damages and hypersensitive to exogenous ROS, suggesting their direct role in ROS scavenging [143,144]. Additionally, the PT modification of DNA also influences gene expression and metabolic rerouting to counter ROS [142-144].

Taken together, CSD represents a central enzyme that mobilizes $S$ towards diverse physiological pathways-ranging from epigenetic regulation, gene expression, and redoxsignaling to steady-state metabolic pathways, indicating the indispensability of CSDs.

\section{A Multi-Layered Regulation System Modulates the Expression and Activity of Cysteine Desulfurase in Bacteria}

\subsection{Transcriptional Level}

The CSD genes are mostly co-transcribed along with genes involved in Fe-S cluster biosynthesis. The expression of isc or suf genes is influenced by either housekeeping-signals such as Fe-S cluster levels [145], or environmental stimulus such as Fe-limitation [145], ROS, RNI [146,147], hypoxia, nutrient starvation, and inside activated macrophages [148-150]. In E. coli, the regulation of ISC and SUF is primarily mediated by the transcription factor IscR with the help of other accessory transcription factors, including OxyR (peroxide responsive regulator), Fur (ferric uptake regulator), and IHF (integration host factor) (Figure 6) $[147,150]$. IscR is a [2Fe-2S] $]^{+}$containing homodimeric protein, which acts as a sensor of cellular Fe-S cluster levels and oxidative stress [151]. The E. coli IscR belongs to the MarA/SoxS/Rob family of transcription factors and encoded by the first gene in the operon iscRSUA-hscBA-fdx [151]. Depending on the [2Fe-2S] ${ }^{+}$cofactor bound status, apo- or holo-IscR exhibit altered binding affinity towards isc promoter $\left(\mathrm{P}_{i s c}\right)$ region. This repression of the isc operon by holo-IscR requires a functional ISC system, which fulfills the Fe-S cluster demand for the cell. Growth under aerobic conditions puts a high demand for Fe-S clusters due to the need for replenishing apo-protein substrates, which competes with IscR cluster occupancy [146,150-152]. Due to the relatively low binding affinity of apoIscR for $[2 \mathrm{Fe}-2 \mathrm{~S}]^{+}$, it tends to remain in the apo-form during high Fe-S demand, leading to alleviating the repression of isc operon $[150,151,153]$. Whereas during anaerobiosis, 
the need for Fe-S enzyme maturation by the ISC system is satisfied, leading to a higher proportion of holo-IscR, which results in the repression of the isc operon $[150,153]$.

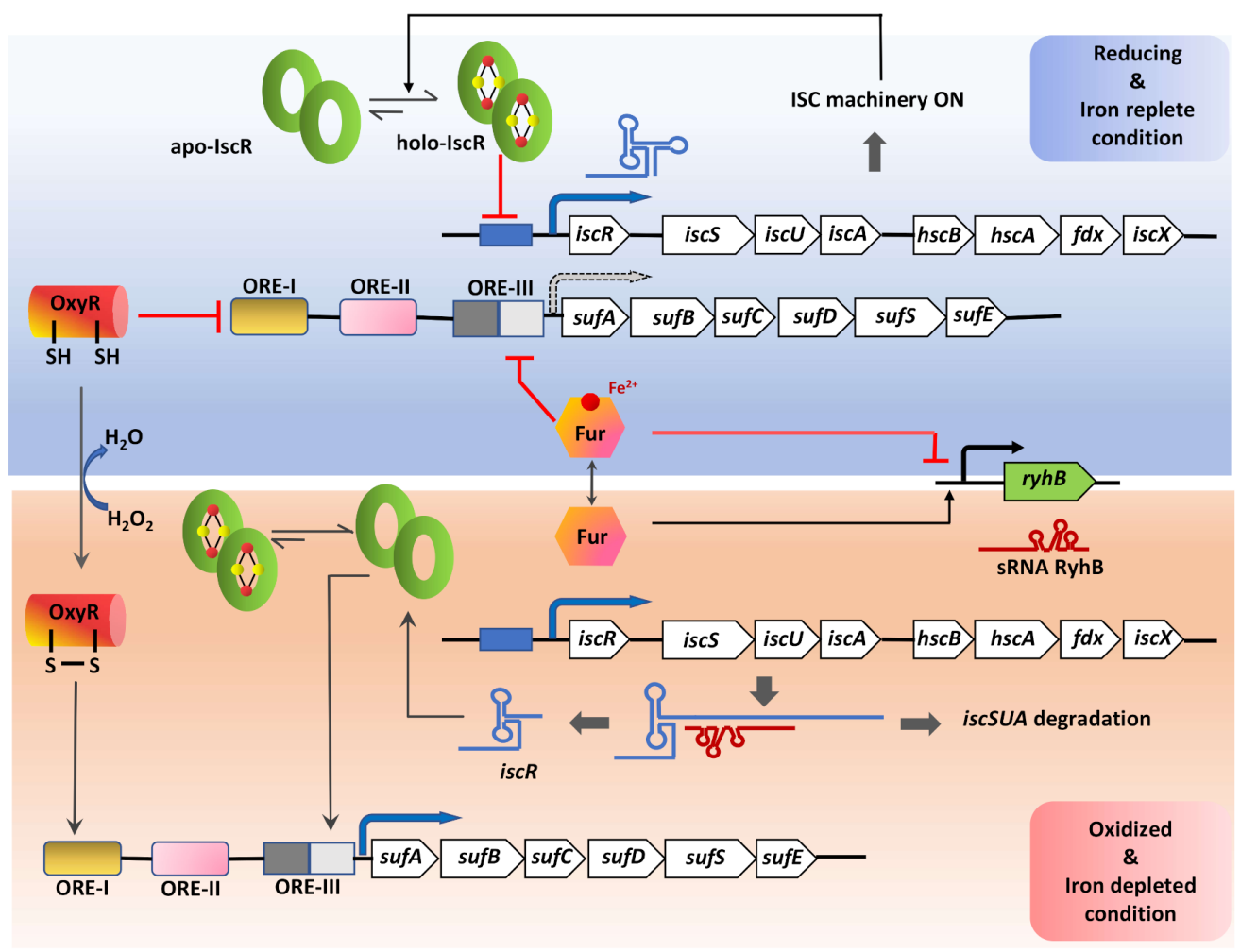

Figure 6. A model for the multistep regulation of Fe-S cluster biogenesis. The expression of the genes involved in Fe-S cluster biogenesis and repair are fine-tuned in accordance with the cellular requirement both under normal growth and stress conditions. This effective regulation is maintained via the role of multiple redox-sensitive transcription factors: IscR, known to regulate both the isc and suf operons with its Fe-S cluster bound (holo-) and unbound (apo-) forms; OxyR, a global regulator that senses $\mathrm{H}_{2} \mathrm{O}_{2}$; Fur, which senses the availability of iron. Transcript level regulation of the housekeeping ISC machinery is executed by the small non-coding RNA, RhyB, that itself is under the control of the iron-deplete/ replete form of the Fur transcription factor. Under iron-replete conditions, holo-Fur inhibits the transcription of $r h y B$, but during iron starvation, apo-Fur increases and activates transcription of $r h y B$ that binds to the isc transcript at the iscS Shine-Dalgarno locus leading to its degradation, leaving the iscR transcript intact due to the stability imparted by its secondary structure. This, in turn, increases apo-IscR, which then binds to the ORE-III sequence upstream of the suf operon. Arrow with black dotted border indicates reduced expression of the suf operon under reducing and iron-replete conditions.

The suf operon in most Gram-negative bacteria is shown to be functional under conditions of high demands for Fe-S cluster biogenesis and repair (e.g., iron starvation and oxidative stress) $[146,150]$. The suf operon (sufABCDSE) in E. coli contains an upstream regulatory region comprising of three cis-acting oxidant responsive elements (ORE-I, II, III) that serve as the interacting sites for factors like OxyR, IHF, IscR, and Fur $[150,153]$. In the presence of an oxidizing environment, the oxidized-OxyR binds to the ORE-I site facilitating interaction with RNA polymerase through a loop formed by IHF bound to the ORE-II site and induces expression [153]. Expression of suf is also controlled by Fur, which senses cellular- $\mathrm{Fe}^{2+}$ levels. suf expression is maintained at minimal levels by Fur mediated repression in reducing or Fe-abundant conditions by binding to ORE-III [153]. Interestingly, apo-IscR also binds to the ORE-III site and activates the expression of suf in a mutually exclusive manner to Fur binding [153]. This implies that under $\mathrm{Fe}^{2+}$-replete conditions, the SUF system will be repressed by dual control of Fur and IscR. 
Unlike Gram-negative bacteria, Gram-positive bacteria generally encode for suf operon $[45,150]$. This suggests the absence of IscR mediated regulation and the involvement of alternate regulatory mechanisms. Cyanobacteria (e.g., Synechocystis sp.) and $M t b$ harbors a SUF system that lacks sufA but contains a regulatory gene sufR. Similar to $i s c R$, sufR encodes for a Fe-S cluster containing transcriptional repressor of the suf operon [52,153-156]. Synechocystis sp. also shows two genes encoding for IscS-like CSD elsewhere in the genome [155]. Similarly, $M t b$ genome consists of a standalone iscS gene, encoding a functional CSD [52,76]. Intriguingly, this $M t b i s c S$ transcript is among the $26 \%$ of $M t b$ genes that form a leaderless transcript, thus marking yet another undiscovered way of regulating CSDs [157].

\subsection{Post-Transcriptional Level}

The ISC system is post-transcriptionally regulated by a small regulatory RNA (sRNA), RyhB. RyhB expression is regulated by Fur, which remains in holo-form $\left(\mathrm{Fe}^{2+}\right)$ under Fe replete conditions. Holo-Fur binds upstream of the $r y h B$ sequence and inhibits its expression [158,159]. In contrast, under iron-limiting conditions, RyhB is transcribed and binds to the polycistronic iscRSUA mRNA at the iscS Shine-Dalgarno sequence. This RhyB-mRNA complex further recruits the ribonuclease RNaseE to initiate degradation of the downstream iscSUA transcript, leaving the IscR-encoding part intact $[158,159]$. This causes unbalanced translation to form only apo-IscR, which then activates the suf operon. Therefore, the sRNA RyhB does not interact with the suf operon directly but regulates the expression of suf genes by modulating the expression of IscR (Figure 6) [150,159].

\subsection{Post-Translational/Enzymatic Level}

Multiple factors regulate CSD enzymatic activity. The activity of SufS is increased upon interaction with the SufBCD complex in E. coli and SufU in B. subtilis and Enterococcus faecalis $[36,160,161]$. In eukaryotes, a small accessory protein, Frataxin (Yfh1), interacts with CSD Nfs1 and scaffold protein Isu1 to aid Fe-S cluster biogenesis [162]. Frataxin is essential in humans, and its deletion impairs Fe-S homeostasis and causes neurodegenerative disease Friedreich's ataxia [162]. Frataxin homolog in bacteria, CyaY can bind $\mathrm{Fe}^{2+}$ or $\mathrm{Fe}^{3+}$ (iron chaperone) and can donate Fe for Fe-S cluster biogenesis in vitro [163-165]. However, cyaY is dispensable in prokaryotes during normal growth conditions [166]. Interestingly, CyaY has been shown to counteract oxidative stress and functions to repair Fe-S-containing enzymes such as Respiratory Complex I (NdhI), and Acn [167,168]. In vitro studies have demonstrated that [2Fe-2S]-Ferredoxin physically interacts with CSD and either donates an electron for Fe-S assembly or $\mathrm{Fe}^{2+}$ donor [169]. In addition to this, CyaY also competes with Ferredoxin and IscU as an iron-dependent inhibitor of CSD activity in vitro [169]. Therefore, the role of frataxin-homologs in prokaryotes is incompletely understood and needs to be further investigated. For more details, readers are encouraged to refer to the published article [10].

CSD activity is also redox-regulated and mediated by the thioredoxin system (TrxA (Thioredoxin)/ TrxR (Thioredoxin reductase)) [170]. In vitro biochemical assays demonstrated that the reactions of B. subtilis SufS:SufU sulfurtransferase and TrxR to be coupled, involving NADPH-dependent reduction of SufU-persulfide. Inactivation or deletion of the Trx system impaired the activity of Fe-S cluster containing enzymes, suggesting a link between cellular redox buffer-thioredoxin and CSD activity.

\section{Cysteine Desulfurase Maintain Intracellular Redox Homeostasis and Impart Oxidative-Stress Defense in Diverse Bacterial Species}

\subsection{Role in Sustaining Intracellular Redox Balance}

CSD influences the flux of $\mathrm{Fe}\left(\mathrm{Fe}^{2+}, \mathrm{Fe}^{3+}\right)$ and $\mathrm{S}\left(\mathrm{S}^{2-}\right)$ into diverse cellular pathways through Fe-S biogenesis. Fe-S clusters are redox-active moieties that are evidently both the cause and target of oxidative stress-mediated damage [171]. $\mathrm{ROS}\left(\mathrm{O}_{2}{ }^{\bullet-}\right.$ and $\left.\mathrm{H}_{2} \mathrm{O}_{2}\right)$ oxidize Fe-S clusters, especially from dehydratases, leading to the leaching of $\mathrm{Fe}$ and disintegration 
of Fe-S clusters [72]. This reaction has two primary consequences: First, the increase in labile $\mathrm{Fe}^{2+}$ pool feeds into the Fenton reaction to generate highly reactive ${ }^{\bullet} \mathrm{OH}$ radicals, which induce oxidative damage to DNA, lipids, and proteins [172]. Second, the disintegration of Fe-S clusters renders the enzymes inactive. Indeed, mutants for CSD lead to decreased carbon catabolism through inhibition of TCA cycle enzyme Acn, decreased respiration, and ATP production, all of which are essential for cellular metabolism and growth [51,173]. Additionally, disruption of the electron transport chain (ETC) can potentially cause electron leaks to $\mathrm{O}_{2}$ generating $\mathrm{O}_{2}{ }^{\bullet-}[174,175]$. Therefore, constant maintenance of Fe-S cluster biogenesis and repair by CSD is essential in decreasing ETC-generated ROS and thwarting ROS-mediated damages.

In addition to ETC, intracellular ROS is generated when electrons are adventitiously transferred to $\mathrm{O}_{2}$ via flavoenzymes, transition-metal centers, and respiratory quinonecontaining enzymes [176]. Cells keep this basal-ROS below toxic levels via antioxidant enzymes, regulating metabolic fluxes and repair proteins. Interestingly, lipoic acid, one of the end-products of CSD activity, participates in redox metabolism by functioning as a redox couple. Lipoate (oxidized)/dihydrolipoate (reduced) can quench an array of toxic free radicals, which include ${ }^{\bullet} \mathrm{OH}$, peroxyl radical, $\mathrm{O}_{2}{ }^{\bullet-}$, and singlet oxygen species $[98,177,178]$. In addition to acting directly as free radical quenchers, dihydrolipoate works synergistically with multiple antioxidant systems such as vitamin C, glutathione, coenzyme Q10, and vitamin E to maintain ambient redox-homeostasis [179].

\subsection{Function of CSD in Neutralizing Exogenous Redox Stress}

Direct implications of CSD in defense against oxidative stress have been documented in several pathogenic species. The intracellular pathogen $M t b$, is exposed to various oxidative and nitrosative insults within alveolar macrophages [180]. Interestingly, iscS deleted $M t b$ displayed hypersensitivity towards $\mathrm{H}_{2} \mathrm{O}_{2}$, and the overexpressing strain was more resistant to oxidative stress implying its protective role [51]. Mtb IscS directly interacted to coordinate the activity of essential Fe-S cluster containing proteins (e.g., Acn and SdhB) [51]. In addition, $M t b$ IscS assembles the Fe-S cluster of the redox-active transcription factor, WhiB3, in vitro [71]. WhiB3 owing to its redox-sensitive Fe-S cluster, senses host-derived signals such as ROS, RNI, and low $\mathrm{pH}$ to assist $\mathrm{Mtb}$ in maintaining redox balance and persist in vivo [71,181]. However, in addition to IscS, Mtb harbors a second putative CSD SufS (Rv1464) in the suf operon (rv1460-rv1466). It is unknown how much SufS contributes to the total Mtb-CSD activity under normal growth conditions and stress. Therefore, dissecting the contribution of SufS in Mtb pathogenesis remains to be elucidated.

A similar role of CSD in defense against antibiotic-induced ROS has been documented in gut-pathogens. Antibiotic administration increases gut $\mathrm{O}_{2}$ levels, unlike the hypoxic state that prevails typically in the gut epithelium [182]. During infection, Clostridium difficile IscS2 impart resistance to toxic $\mathrm{O}_{2}$ levels, thereby allowing successful murine gut invasion [21]. The loss of iscS2 in C. difficile led to growth and sporulation defects in addition to being sensitive to the $2 \% \mathrm{O}_{2}$ in the gut [21]. Helicobacter pylori, another gastric pathogen, poses a singular NIF-system for its Fe-S cluster biosynthesis [183]. Transcriptional studies revealed the nifS-nifU operon to be highly upregulated in the presence of $12 \% \mathrm{O}_{2}$ or when $H$. pylori were cultured in Fe-rich conditions, suggesting the role of Fe-S biogenesis and repair as means to limit $\mathrm{O}_{2}$-toxicity [183]. Comparable data are recapitulated in parasitic protozoanLeishmania donovani. This pathogen faces oxidative stress within phagocytes, during hemedegradation and complement lysis in blood meal [24]. L. donovani circumvents damage of its labile Fe-S clusters in the presence of ROS generators menadione and amphotericin-B (a clinically- relevant drug against visceral leishmaniasis) by upregulating $L d$-iscS [24].

E. coli contains three Fe-S cluster biogenesis and repair machinery, namely SUF, ISC, and CSD systems. The E. coli SUF S-transfer system exhibits higher CSD activity under physiological substrate conditions and upon exposure to $\mathrm{H}_{2} \mathrm{O}_{2}$ compared to the analogous ISC system [184]. Additionally, the catalytic cysteine $\left(\mathrm{C}_{328}\right)$ of IscS was more susceptible to 
dead-end oxidative modifications than that of SufS $\left(\mathrm{C}_{364}\right)$ [184] in the presence of $\mathrm{H}_{2} \mathrm{O}_{2}$. On this basis, the SUF-system is more suited for Fe-S cluster biogenesis under exogenous redox stress $[89,107,155]$. E. coli IscS is also involved in redox-dependent $\mathrm{H}_{2} \mathrm{~S}$ biogenesis, where reducing conditions stimulate $\mathrm{H}_{2} \mathrm{~S}$ production [138]. The $\mathrm{H}_{2} \mathrm{~S}$ gas is known to protect diverse bacteria from oxidative stress and antibiotics $[185,186]$. It maintains growth and bioenergetics under hypoxia as well $[137,138]$.

Nitrogen-fixing cyanobacteria Anabaena encodes four CSD ORFs (all1457, alr2495, alr3088, and alr2505). Alr 2495 (annotated as SufS) and accessory protein AsaE on overexpression, reduced intracellular ROS in the presence of $\mathrm{H}_{2} \mathrm{O}_{2}$ and improved survival [22]. $\mathrm{O}_{2}$-induced expression of SufS2 was also important for survival in Agrobacterium tumefaciens [23]. Toxic potassium tellurite $\left(\mathrm{K}_{2} \mathrm{TeO}_{3}\right)$ has a deleterious effect on bacteria due to the oxidation of cellular thiols such as glutathione (GSH) [187]. Geobacillus stearothermophilus IscS, when expressed in E. coli showed cellular resistance to $\mathrm{K}_{2} \mathrm{TeO}_{3}$. A similar observation was made in Staphylococcus aureus, E. coli, and Rhodobacter sphaeroides [188,189]. Altogether, these studies indicate the importance and association of CSD in controlling intracellular ROS levels, which confers protection against environmental and host-induced redox stress.

\section{Cysteine Desulfurase Is a Potential Drug Target-Candidate}

Recent studies suggest that CSD could be an ideal drug target for infectious pathogens. Prokaryotic SUF machinery is significantly distinct from their eukaryotic counterparts [44,190], and targeting it could affect a multitude of essential functions dependent on Fe-S cluster biogenesis $[4,5]$. Moreover, differential expression of SUF and IscU has been shown to increase resistance against aminoglycosides, suggesting that antibiotic efficacy is linked to CSD-driven Fe-S homeostasis [20,173,191].

Studies by Kohanski et al., provided direct evidence linking the efficacy of three diverse bactericidal antibiotics - ampicillin ( $\beta$-lactam), kanamycin (aminoglycoside), and norfloxacin (fluoroquinolone) - with IscS in E. coli [20]. These antibiotics trigger ROSgeneration as a secondary mechanism to induce killing. Interestingly, E. coli-iscS deleted strain accumulated less ${ }^{\bullet} \mathrm{OH}$ radical upon antibiotic treatment and exhibited reduced lethality [20]. This led the authors to propose that Fe released from the ROS-damaged Fe-S clusters stimulate the generation of Fenton-mediated ${ }^{\bullet} \mathrm{OH}$ radical during antibiotic exposure. In E. coli iscS mutant, the depleted Fe-S cluster pools impair Fenton reaction and contribute to reduced susceptibility to antibiotics. However, Ezraty et al., found that E. coli iscS mutant is resistant to aminoglycoside due to defects in Fe-S cluster maturation of Ndh1/2 and complex 2 (Sdh), which led to aberrant proton-motive force (PMF) and inefficient uptake of aminoglycoside [173]. Interestingly, clinically resistant-isolates derived from visceral leishmaniasis patients, which are unresponsive to Amphotericin-B treatment, showed decreased CSD-expression and activity, along with reduced ROS levels than the sensitive strain [24]. Taken together, these studies suggest that active CSD potentiates antibiotics efficacy and CSD inhibition induces antibiotic resistance. Although CSD-activity appears to increase the bactericidal efficacy of antibiotics, it is important to note that, in multiple studies, targeting this enzyme has better treatment outcomes probably by disturbing multiple essential metabolic pathways where it serves as the S-donor (Figure 7).

Several inhibitors of CSDs have been previously reported. Firstly, cysteine analogs, Lallylglycine, and L-vinylglycine, irreversibly inactivated NifS by forming a y-methylcystathionyl or cystathionyl residue, respectively, through nucleophilic attack by an active site cysteinyl residue on the corresponding analog-pyridoxal phosphate adduct $[63,192]$. Additionally, alkylating agents such as 1,5-I-AEDANS significantly inhibited IscS and NifS activity [192]. As CSDs are PLP-dependent enzymes, molecules that form stable adducts with PLP cofactor can irreversibly inhibit CSDs [63]. Charan et al. demonstrated that PLP-fold type1 (aspartate aminotransferase family) targeting molecule, D-cycloserine (DCS), forms an adduct with the PLP-cofactor bound to Plasmodium falciparum PfSufS (PfSufS-PLPDCS; 3-hydroxyisoxazole-pyridoxamine derivative), thereby inhibiting PfSufS activity and impeding the growth of the parasite [193]. The 50\% inhibitory concentration (IC $\left.{ }_{50}\right)$ of 
DCS against $P$. falciparum is $\sim 29 \mu \mathrm{M}$. Interestingly, DCS also displays inhibitory activity against $M t b$ and is in clinical use as a second-line anti-TB drug [193-195]. However, future experimentations are needed to examine if DCS inhibits Mtb SufS. In sum, the inhibition of SufS by DCS provides a proof of concept for designing inhibitors targeting the PLP moiety of this primary enzyme of S-mobilization and Fe-S biogenesis pathway.

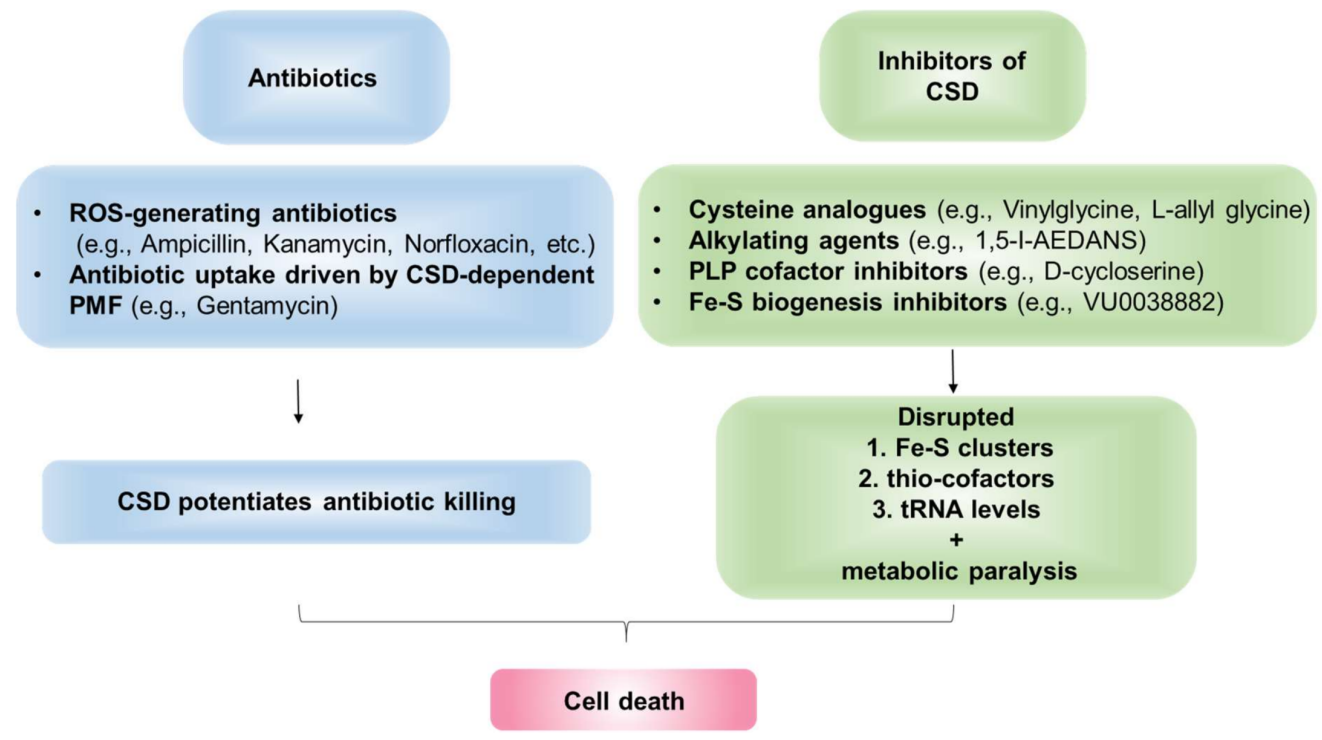

Figure 7. CSD as a drug target. CSDs mediate cellular death via potentiating the effect of existing antibiotics. Additionally, CSDs can be targeted by specific inhibitors to disrupt cellular physiology.

SufS delivers $S$ from cysteine to SufBCD complex during the generation of Fe-S clusters [196]. In a significant discovery, Choby et al. identified small-molecule VU0038882 ('882) as a first-in-class inhibitor of Fe-S cluster machinery in S. aureus [197]. '882 directly interacts with SufC in complex with SufB and SufD to inhibit Fe-S assembly, thereby disrupting CoA homeostasis and multiple other metabolic pathways [197]. Indeed, '882 is extremely toxic to both aerobic $\left(\mathrm{IC}_{50} \sim 5 \mu \mathrm{M}\right)$ and anaerobic $\left(\mathrm{IC}_{50} \sim 162 \mu \mathrm{M}\right)$ S. aureus [197], and a '882-derivative molecule significantly reduced the burden of $S$. aureus in a miceinfection model [198]. In sum, the deleterious and pleiotropic effects of ' 882 are mediated by defective Fe-S cluster assembly, demonstrating ISC/SUF/NIF system as an effective and novel drug target. These findings present the opportunity to develop the ISC/SUF machinery inhibitors as a potential novel therapeutic to control AMR.

\section{Conclusions and Future Directions}

A plethora of literature over the past few decades stands testament to the role of S-relay and CSDs in pathogenic metabolism, virulence, and stress response [4-6]. Cysteine desulfuration remains paramount in incorporating $S$ in coenzymes and cofactors (Fe-S clusters, lipoic acid, biotin, etc.) on which cellular physiology relies. Our review highlights this aspect and describes how central metabolism, transcriptional regulation, DNA, and protein biosynthesis are conjoined by CSDs. Corresponding to the physiological importance, CSDs also influence the pathogenesis of disease-causing organisms. This is emphasized by how pathogenic-CSD manipulates cellular physiology to alleviate drug-induced toxicity and how they evade various host-derived oxidative stresses [20,21,24,51,199]. Moreover, multiple studies wherein "paralogs" of CSD are mutated simultaneously have rendered the organism non-viable. The multi-functionality of CSDs corroborates its essentiality. Therefore, CSDs should be extensively explored as a potential drug target that may augment existing drug regimens. 
Author Contributions: Conceptualization, M.D. and A.S.; writing-original draft preparation, M.D. and A.D.; writing—review and editing, S.S., M.D., A.D. and A.S.; visualization, M.D.; supervision, A.S.; project administration, M.D.; and funding acquisition, A.S. All authors have read and agreed to the published version of the manuscript.

Funding: "This research was funded by Wellcome Trust-Department of Biotechnology (DBT) India Alliance, grant number IA/S/16/2/502700 (A.S.) and partially by DBT grants BT/PR13522/COE/34/ 27/2015, BT/PR29098/Med/29/1324/2018 and BT/HRD/NBA/39/07/2018-19 (A.S.), DBT-IISc Partnership Program grant 22-0905-0006-05-987 436, and the Infosys Foundation" and "The APC was funded by IA/S/16/2/502700 (A.S.)". A.S. is a senior fellow of Wellcome Trust-DBT India Alliance.

Conflicts of Interest: The authors declare no conflict of interest.

\begin{abstract}
Abbreviations
$\mathrm{S}$, sulfur; CSD, cysteine desulfurase; $\mathrm{SO}_{4}{ }^{2--}$, sulfate; $\mathrm{S}^{2-}$, sulfide; $\mathrm{S}_{2} \mathrm{O}_{3}{ }^{2-}$, thiosulfate; $\mathrm{R}_{-} \mathrm{SO}_{3}{ }^{-}$, sulfonate; PLP, pyridoxal-5' -phosphate; Fe-S cluster, iron-sulfur cluster; NIF, nitrogen fixation; ISC, iron-sulfur cluster system; SUF, sulfur mobilization; NAD, nicotinamide adenine dinucleotide; TLM, thiolactomycin; AMR, antimicrobial resistance; tRNA, transfer RNA; $\mathrm{H}_{2} \mathrm{O}_{2}$, hydrogen peroxide; $\mathrm{O}_{2}{ }^{-}$, superoxide; ${ }^{\bullet} \mathrm{OH}$, hydroxyl radical; $\mathrm{NO}$, nitric oxide; FNR, fumarate nitrate reductase; ROS, reactive oxygen species; RNI, reactive nitrogen species; CsdA, cysteine sulfinate desulfinase A; C-DES, PLP-dependent L-cyst(e)ine C-S-lyase; Mtb, Mycobacterium tuberculosis; Acn, aconitase; SdhB, succinate dehydrogenase; TCA, tricarboxylic acid; s2U, 2-thiouridine; s4U, 4-thiouridine; s2C, 2-thiocytidine; ms2A, 2-methylthioadenosine; s2T54, 2-thiouridothymidine; FdhH, formate dehydrogenase H; LipA, lipoate synthase; SAM, S-adenosyl L-methionine; PDH, pyruvate dehydrogenase; $\mathrm{KGD}, \alpha$-ketoglutarate dehydrogenase; $\mathrm{BCKDH}$, branched-chain keto acid dehydrogenase; ACCs, acyl-CoA carboxylases; ACP, acyl carrier protein; BPL, biotin protein ligase enzymes; KAPAS, 7-keto8-aminopelargonic acid synthase; DAPAS, 7,8-diaminopelargonic acid synthase; DTBS, dethiobiotin synthase; BS, biotin synthase; TPP, thiamine pyrophosphate; HMP-PP, 4-amino-5-hydroxymethyl-2methylpyrimidine pyrophosphate; THZ-P, 4-methyl-5-( $\beta$-hydroxymethyl) thiazole phosphate; MPT, molybdopterin; Moco, molybdopterin cofactor; $\mathrm{XO}$, xanthine oxidase; SO, sulfite oxidase; DMSO, dimethyl sulfoxide; $\mathrm{H}_{2} \mathrm{~S}$, hydrogen sulfide; 3-MST, 3-mercaptopyruvate sulfurtransferase; $\mathrm{Na}_{2} \mathrm{~S}$, sodium sulfide; PT, phosphorothioate; RM, restriction-modification; sRNA, small regulatory RNA; ETC, electron transport chain; $\mathrm{K}_{2} \mathrm{TeO}_{3}$, potassium tellurite; $\mathrm{GSH}$, glutathione; PMF, proton-motive force; $\mathrm{IC}_{50}$, half maximal inhibitory concentration.
\end{abstract}

\title{
References
}

1. Kessler, D. Enzymatic Activation of Sulfur for Incorporation into Biomolecules in Prokaryotes. FEMS Microbiol. Rev. 2006, 30, 825-840. [CrossRef] [PubMed]

2. Guédon, E.; Martin-Verstraete, I. Cysteine Metabolism and Its Regulation in Bacteria. In Amino Acid Biosynthesis Pathways, Regulation and Metabolic Engineering; Springer: Berlin/Heidelberg, Germany, 2006; Volume 5, pp. 195-218.

3. Paulsen, C.E.; Carroll, K.S. Cysteine-mediated Redox Signaling: Chemistry, Biology, and Tools for Discovery. Chem. Rev. 2013, 113, 4633-4679. [CrossRef] [PubMed]

4. Mihara, H.; Esaki, N. Bacterial Cysteine Desulfurases: Their Function and Mechanisms. Appl. Microbiol. Biotechnol. 2002, 60, 12-23. [CrossRef] [PubMed]

5. Hidese, R.; Mihara, H.; Esaki, N. Bacterial Cysteine Desulfurases: Versatile Key Players in Biosynthetic Pathways of SulfurContaining Biofactors. Appl. Microbiol. Biotechnol. 2011, 91, 47-61. [CrossRef] [PubMed]

6. Black, K.A.; Santos, P.C.D. Shared-intermediates in the Biosynthesis of Thio-cofactors: Mechanism and Functions of Cysteine Desulfurases and Sulfur Acceptors. Biochim. Biophys. Acta Mol. Cell Res. 2015, 1853, 1470-1480. [CrossRef]

7. Zheng, L.; White, R.H.; Cash, V.L.; Jack, R.F.; Dean, D.R. Cysteine Desulfurase Activity Indicates a Role for NIFS in Metallocluster Biosynthesis. Proc. Natl. Acad. Sci. USA 1993, 90, 2754-2758. [CrossRef]

8. Zheng, L.; Cash, V.L.; Flint, D.H.; Dean, D.R. Assembly of Iron-Sulfur Clusters. Identification of an iscSUA-hscBA-fdx Gene Cluster from Azotobacter vinelandii. J. Biol. Chem. 1998, 273, 13264-13272. [CrossRef]

9. Forouhar, F.; Arragain, S.; Atta, M.; Gambarelli, S.; Mouesca, J.M.; Hussain, M.; Xiao, R.; Kieffer-Jaquinod, S.; Seetharaman, J.; Acton, T.B.; et al. Two Fe-S clusters Catalyze Sulfur Insertion by Radical-SAM methylthiotransferases. Nat. Chem. Biol. 2013, 9, 333-338. [CrossRef]

10. Roche, B.; Agrebi, R.; Huguenot, A.; Ollagnier-de-Choudens, S.; Barras, F.; Py, B. Turning Escherichia coli into a FrataxinDependent Organism. PLoS Genet. 2015, 11, e1005134. [CrossRef] 
11. Jacobson, M.R.; Cash, V.L.; Weiss, M.C.; Laird, N.F.; Newton, W.E.; Dean, D.R. Biochemical and Genetic Analysis of the nifUSVWZM Cluster from Azotobacter vinelandii. Mol. Gen. Genet. 1989, 219, 49-57. [CrossRef]

12. Oishi, H.; Noto, T.; Sasaki, H.; Suzuki, K.; Hayashi, T.; Okazaki, H.; Ando, K.; Sawada, M. Thiolactomycin, a New Antibiotic: I. Taxonomy of the Producing Organism, Fermentation, and Biological Properties. J. Antibiot. 1982, 35, 391-395. [CrossRef] [PubMed]

13. Noto, T.; Miyakawa, S.; Oishi, H.; Endo, H.; Okazaki, H. Thiolactomycin, a New Antibiotic III. In vitro Antibacterial Activity. J. Antibiot. 1982, 35, 401-410. [CrossRef] [PubMed]

14. Tao, W.; Yurkovich, M.E.; Wen, S.; Lebe, K.E.; Samborskyy, M.; Liu, Y.; Yang, A.; Liu, Y.; Ju, Y.; Deng, Z.; et al. A Genomics-led Approach to Deciphering the Mechanism of Thiotetronate Antibiotic Biosynthesis. Chem. Sci. 2016, 7, 376-385. [CrossRef] [PubMed]

15. Schaeffer, M.L.; Agnihotri, G.; Volker, C.; Kallender, H.; Brennan, P.J.; Lonsdale, J.T. Purification and Biochemical Characterization of the Mycobacterium tuberculosis Beta-ketoacyl-acyl Carrier Protein Synthases KasA and KasB. J. Biol. Chem. 2001, 276, 47029-47037. [CrossRef] [PubMed]

16. Waller, R.F.; Keeling, P.J.; Donald, R.G.; Striepen, B.; Handman, E.; Lang-Unnasch, N.; Cowman, A.F.; Besra, G.S.; Roos, D.S.; McFadden, G.I. Nuclear-encoded Proteins Target to the Plastid in Toxoplasma gondii and Plasmodium falciparum. Proc. Natl. Acad. Sci. USA 1998, 95, 12352-12357. [CrossRef] [PubMed]

17. Slayden, R.A.; Lee, R.E.; Armour, J.W.; Cooper, A.M.; Orme, I.M.; Brennan, P.J.; Besra, G.S. Antimycobacterial Action of Thiolactomycin: An Inhibitor of Fatty Acid and Mycolic Acid Synthesis. Antimicrob. Agents Chemother. 1996, 40, $2813-2819$. [CrossRef]

18. Jones, S.M.; Urch, J.E.; Brun, R.; Harwood, J.L.; Berry, C.; Gilbert, I.H. Analogues of Thiolactomycin as Potential Anti-malarial and Anti-trypanosomal Agents. Bioorganic Med. Chem. 2004, 12, 683-692. [CrossRef] [PubMed]

19. Novaes, R.D.; Teixeira, A.L.; de Miranda, A.S. Oxidative Stress in Microbial Diseases: Pathogen, Host, and Therapeutics. Oxidative Med. Cell. Longev. 2019, 2019, 10-12. [CrossRef]

20. Kohanski, M.A.; Dwyer, D.J.; Hayete, B.; Lawrence, C.A.; Collins, J.J. A Common Mechanism of Cellular Death Induced by Bactericidal Antibiotics. Cell 2007, 130, 797-810. [CrossRef] [PubMed]

21. Giordano, N.; Hastie, J.L.; Smith, A.D.; Foss, E.D.; Gutierrez-Munoz, D.F.; Carlson, P.E. Cysteine Desulfurase IscS2 Plays a Role in Oxygen Resistance in Clostridium difficile. Infect. Immun. 2018, 86, 1-8. [CrossRef]

22. Banerjee, M.; Chakravarty, D.; Ballal, A. Molecular Basis of Function and the Unusual Antioxidant Activity of a Cyanobacterial Cysteine Desulfurase. Biochem. J. 2017, 474, 2435-2447. [CrossRef]

23. Bhubhanil, S.; Niamyim, P.; Sukchawalit, R.; Mongkolsuk, S. Cysteine Desulphurase-encoding Gene sufS2 is Required for the Repressor Function of RirA and Oxidative Resistance in Agrobacterium tumefaciens. Microbiology 2014, 160, 79-90. [CrossRef]

24. Singh, K.P.; Zaidi, A.; Anwar, S.; Bimal, S.; Das, P.; Ali, V. Reactive Oxygen Species Regulates Expression of Iron-sulfur Cluster Assembly Protein IscS of Leishmania donovani. Free Radic. Biol. Med. 2014, 75, 195-209. [CrossRef] [PubMed]

25. Jacobson, M.R.; Brigle, K.E.; Bennett, L.T.; Setterquist, R.A.; Wilson, M.S.; Cash, V.L.; Beynon, J.; Newton, W.E.; Dean, D.R. Physical and Genetic Map of the Major nif Gene Cluster from Azotobacter vinelandii. J. Bacteriol. 1989, 171, 1017-1027. [CrossRef]

26. Zheng, L.; White, R.H.; Cash, V.L.; Dean, D.R. Mechanism for the Desulfurization of L-Cysteine Catalyzed by the nifS Gene Product. Biochemistry 1994, 33, 4714-4720. [CrossRef]

27. Flint, D.H. Escherichia coli Contains a Protein that is Homologous in Function and N-terminal Sequence to the Protein Encoded by the nifS Gene of Azotobacter vinelandii and that can Participate in the Synthesis of the Fe-S Cluster of Dihydroxy-acid Dehydratase. J. Biol. Chem. 1996, 271, 16068-16074. [CrossRef]

28. Mihara, H.; Maeda, M.; Fujii, T.; Kurihara, T.; Hata, Y.; Esaki, N. A nifS-like Gene, csdB, Encodes an Escherichia coli Counterpart of Mammalian Selenocysteine Lyase: Gene cloning, Purification, Characterization, and Preliminary X-ray Crystallo-graphic Studies. J. Biol. Chem. 1999, 274, 14768-14772. [CrossRef] [PubMed]

29. Mihara, H.; Kurihara, T.; Yoshimura, T.; Soda, K.; Esaki, N. Cysteine Sulfinate Desulfinase, a NIFS-like Protein of Escherichia coli with Selenocysteine Lyase and Cysteine Desulfurase Activities: Gene cloning, Purification, and Characterization of a Novel Pyridoxal Enzyme. J. Biol. Chem. 1997, 272, 22417-22424. [CrossRef] [PubMed]

30. Patzer, S.I.; Hantke, K. SufS is a NifS-like Protein, and SufD is Necessary for Stability of the [2Fe-2S] FhuF Protein in Escherichia coli. J. Bacteriol. 1999, 181, 3307-3309. [CrossRef] [PubMed]

31. Dahl, J.U.; Radon, C.; Bühning, M.; Nimtz, M.; Leichert, L.I.; Denis, Y.; Jourlin-Castelli, C.; Iobbi-Nivol, C.; Méjean, V.; Leimkühler, S. The Sulfur Carrier Protein tusA has a Pleiotropic Role in Escherichia coli that also Affects Molybdenum Cofactor Biosynthesis. J. Biol. Chem. 2013, 288, 5426-5442. [CrossRef]

32. Mueller, E.G.; Buck, C.J.; Palenchar, P.M.; Barnhart, L.E.; Paulson, J.L. Identification of a Gene Involved in the Generation of 4-thiouridine in tRNA. Nucleic Acids Res. 1998, 26, 2606-2610. [CrossRef] [PubMed]

33. Ikeuchi, Y.; Shigi, N.; Kato, J.I.; Nishimura, A.; Suzuki, T. Mechanistic Insights into Sulfur Relay by Multiple Sulfur Mediators Involved in Thiouridine Biosynthesis at tRNA Wobble Positions. Mol. Cell 2006, 21, 97-108. [CrossRef]

34. Rajakovich, L.J.; Tomlinson, J.; Santos, P.C.D. Functional Analysis of Bacillus subtilis Genes Involved in the Biosynthesis of 4-thiouridine in tRNA. J. Bacteriol. 2012, 194, 4933-4940. [CrossRef] [PubMed]

35. Yuvaniyama, P.; Agar, J.N.; Cash, V.L.; Johnson, M.K.; Dean, D.R. NifS-directed Assembly of a Transient [2Fe-2S] Cluster within the NifU Protein. Proc. Natl. Acad. Sci. USA 2000, 97, 599. [CrossRef] [PubMed] 
36. Outten, F.W.; Wood, M.J.; Muñoz, F.M.; Storz, G. The SufE Protein and the SufBCD Complex Enhance SufS Cysteine Desulfurase Activity as Part of a Sulfur Transfer Pathway for Fe-S Cluster Assembly in Escherichia coli. J. Biol. Chem. 2003, 278, 45713-45719. [CrossRef] [PubMed]

37. Selbach, B.; Earles, E.; Santos, P.C.D. Kinetic Analysis of the Bisubstrate Cysteine Desulfurase SufS from Bacillus subtilis. Biochemistry 2010, 49, 8794-8802. [CrossRef] [PubMed]

38. Loiseau, L.; Ollagnier-de-Choudens, S.; Lascoux, D.; Forest, E.; Fontecave, M.; Barras, F. Analysis of the Heteromeric CsdA-CsdE Cysteine Desulfurase, Assisting Fe-S Cluster Biogenesis in Escherichia coli. J. Biol. Chem. 2005, 280, 26760-26769. [CrossRef]

39. Bouvier, D.; Labessan, N.; Clémancey, M.; Latour, J.M.; Ravanat, J.L.; Fontecave, M.; Atta, M. TtcA a New tRNA-thioltransferase with an Fe-S Cluster. Nucleic Acids Res. 2014, 42, 7960-7970. [CrossRef]

40. Clausen, T.; Kaiser, J.T.; Steegborn, C.; Huber, R.; Kessler, D. Crystal Structure of the Cystine C-S lyase from Synechocystis: Stabilization of Cysteine Persulfide for Fe-S Cluster Biosynthesis. Proc. Natl. Acad. Sci. USA 2000, 97, 3856-3861. [CrossRef]

41. Leibrecht, I.; Kessler, D. A Novel L-Cysteine/Cystine C-S-lyase Directing [2Fe-2S] Cluster Formation of Synechocystis Ferredoxin. J. Biol. Chem. 1997, 272, 10442-10447. [CrossRef]

42. Kumar, S.; Stecher, G.; Li, M.; Knyaz, C.; Tamura, K. MEGA X: Molecular Evolutionary Genetics Analysis across Computing Platforms. Mol. Biol. Evol. 2018, 35, 1547-1549. [CrossRef] [PubMed]

43. Py, B.; Barras, F. Building Fe-S Proteins: Bacterial Strategies. Nat. Rev. Microbiol. 2010, 8, 436-446. [CrossRef] [PubMed]

44. Lill, R. Function and Biogenesis of Iron-Sulphur Proteins. Nature 2009, 460, 831-838. [CrossRef] [PubMed]

45. Roche, B.; Aussel, L.; Ezraty, B.; Mandin, P.; Py, B.; Barras, F. Iron/sulfur Proteins Biogenesis in Prokaryotes: Formation, Regulation and Diversity. Biochim. Biophys. Acta Bioenerg. 2013, 1827, 455-469. [CrossRef]

46. Outten, F.W. Recent Advances in the Suf Fe-S Cluster Biogenesis Pathway: Beyond the Proteobacteria. Biochim. Biophys. Acta Mol. Cell Res. 2015, 1853, 1464-1469. [CrossRef] [PubMed]

47. Willemse, D.; Weber, B.; Masino, L.; Warren, R.M.; Adinolfi, S.; Pastore, A.; Williams, M.J. Rv1460, a SufR Homologue, is a Repressor of the suf Operon in Mycobacterium tuberculosis. PLoS ONE 2018, 13, e0200145. [CrossRef]

48. Pandey, M.; Talwar, S.; Bose, S.; Pandey, A.K. Iron Homeostasis in Mycobacterium tuberculosis is Essential for Persistence. Sci. Rep. 2018, 8, 17359. [CrossRef]

49. Mashruwala, A.A.; Bhatt, S.; Poudel, S.; Boyd, E.S.; Boyd, J.M. The DUF59 Containing Protein SufT Is Involved in the Maturation of Iron-Sulfur (Fe-S) Proteins during Conditions of High Fe-S Cofactor Demand in Staphylococcus aureus. PLoS Genet. 2016, 12, e1006233. [CrossRef]

50. Tamuhla, T.; Joubert, L.; Willemse, D.; Williams, M.J. SufT is Required for growth of Mycobacterium smegmatis under Iron Limiting Conditions. Microbiology 2020, 166, 296-305. [CrossRef]

51. Rybniker, J.; Pojer, F.; Marienhagen, J.; Kolly, G.S.; Chen, J.M.; Gumpel, E.V.; Hartmann, P.; Cole, S.T. The Cysteine Desulfurase IscS of Mycobacterium tuberculosis is Involved in Iron-sulfur Cluster Biogenesis and Oxidative Stress Defence. Biochem. J. 2014, 459, 467-478. [CrossRef]

52. Huet, G.; Daffé, M.; Saves, I. Identification of the Mycobacterium tuberculosis SUF Machinery as the Exclusive Mycobacterial System of [Fe-S] Cluster Assembly: Evidence for its Implication in the Pathogen's Survival. J. Bacteriol. 2005, 187, 6137-6146. [CrossRef]

53. Kaiser, J.T.; Clausen, T.; Bourenkow, G.P.; Bartunik, H.D.; Steinbacher, S.; Huber, R. Crystal Structure of a NifS-like Protein from Thermotoga maritima: Implications for Iron-sulfur Cluster Assembly. J. Mol. Biol. 2000, 297, 451-464. [CrossRef] [PubMed]

54. Cupp-Vickery, J.R.; Urbina, H.; Vickery, L.E. Crystal Structure of IscS, a Cysteine Desulfurase from Escherichia coli. J. Mol. Biol. 2003, 330, 1049-1059. [CrossRef]

55. Fujii, T.; Maeda, M.; Mihara, H.; Kurihara, T.; Esaki, N.; Hata, Y. Structure of a NifS Homologue: X-ray Structure Analysis of CsdB, an Escherichia coli Counterpart of Mammalian Selenocysteine Lyase. Biochemistry 2000, 39, 1263-1273. [CrossRef] [PubMed]

56. Mihara, H.; Fujii, T.; Kato, S.; Kurihara, T.; Hata, Y.; Esaki, N. Structure of External Aldimine of Escherichia coli CsdB, an IscS/NifS Homolog: Implications for its Specificity Toward Selenocysteine. J. Biochem. 2002, 131, 679-685. [CrossRef] [PubMed]

57. Tirupati, B.; Vey, J.L.; Drennan, C.L.; Bollinger, J.M. Kinetic and Structural Characterization of Slr0077/SufS, the Essential Cysteine Desulfurase from Synechocystis sp. PCC 6803. Biochemistry 2004, 43, 12210-12219. [CrossRef] [PubMed]

58. Grishin, N.V.; Phillips, M.A.; Goldsmith, E.J. Modeling of the Spatial Structure of Eukaryotic Ornithine Decarboxylases. Protein Sci. 1995, 4, 1291-1304. [CrossRef] [PubMed]

59. Schneider, G.; Käck, H.; Lindqvist, Y. The Manifold of Vitamin B6 Dependent Enzymes. Structure 2000, 8, 1-6. [CrossRef]

60. Nakamura, R.; Hikita, M.; Ogawa, S.; Takahashi, Y.; Fujishiro, T. Snapshots of PLP-substrate and PLP-product External Aldimines as Intermediates in Two Types of Cysteine Desulfurase Enzymes. FEBS J. 2020, 287, 1138-1154. [CrossRef]

61. Nilsson, K.; Lundgren, H.K.; Hagervall, T.G.; Björk, G.R. The Cysteine Desulfurase IscS is Required for Synthesis of all Five Thiolated Nucleosides Present in tRNA from Salmonella enterica Serovar Typhimurium. J. Bacteriol. 2002, 184, $6830-6835$. [CrossRef]

62. Dunkle, J.A.; Bruno, M.R.; Outten, F.W.; Frantom, P.A. Structural Evidence for Dimer-interface-driven Regulation of the Type II Cysteine Desulfurase, SufS. Biochemistry 2019, 58, 687-696. [CrossRef]

63. Eliot, A.C.; Kirsch, J.F. Pyridoxal Phosphate Enzymes: Mechanistic, Structural, and Evolutionary Considerations. Annu. Rev. Biochem. 2004, 73, 383-415. [CrossRef] [PubMed] 
64. Behshad, E.; Bollinger, J.M. Kinetic Analysis of Cysteine Desulfurase CD0387 from Synechocystis sp. PCC 6803: Formation of the Persulfide Intermediate. Biochemistry 2009, 48, 12014-12023. [CrossRef] [PubMed]

65. Mueller, E.G. Trafficking in Persulfides: Delivering Sulfur in Biosynthetic Pathways. Nat. Chem. Biol. 2006, 2, 185-194. [CrossRef] [PubMed]

66. Santos, P.C.D. B. subtilis as a Model for Studying the Assembly of Fe-S Clusters in Gram-Positive Bacteria. In Methods in Enzymology; Academic Press Inc.: Cambridge, MA, USA, 2017; Volume 595, pp. 185-212.

67. Giles, G.I.; Tasker, K.M.; Jacob, C. Hypothesis: The Role of Reactive Sulfur Species in Oxidative Stress. Free Radic. Biol. Med. 2001, 31, 1279-1283. [CrossRef]

68. Giles, G.I.; Jacob, C. Reactive Sulfur Species: An Emerging Concept in Oxidative Stress. Biol. Chem. 2002, 383, 375-388. [CrossRef]

69. Jacob, C.; Giles, G.I.; Giles, N.M.; Sies, H. Sulfur and Selenium: The Role of Oxidation State in Protein Structure and Function. Angew. Chem. Int. Ed. 2003, 42, 4742-4758. [CrossRef] [PubMed]

70. Selbach, B.P.; Pradhan, P.K.; Santos, P.C.D. Protected Sulfur Transfer Reactions by the Escherichia coli Suf System. Biochemistry 2013, 52, 4089-4096. [CrossRef]

71. Singh, A.; Guidry, L.; Narasimhulu, K.V.; Mai, D.; Trombley, J.; Redding, K.E.; Giles, G.I.; Lancaster, J.R., Jr.; Steyn, A.J. Mycobacterium tuberculosis WhiB3 Responds to $\mathrm{O}_{2}$ and Nitric oxide via its [4Fe-4S] Cluster and is Essential for Nutrient Starvation Survival. Proc. Natl. Acad. Sci. USA 2007, 104, 11562-11567. [CrossRef]

72. Imlay, J.A. Iron-sulfur Clusters and the Problem with Oxygen. Mol. Microbiol. 2006, 59, 1073-1082. [CrossRef]

73. Johnson, D.C.; Dean, D.R.; Smith, A.D.; Johnson, M.K. Structure, Function, and Formation of Biological Iron-sulfur Clusters. Annu. Rev. Biochem. 2005, 74, 247-281. [CrossRef] [PubMed]

74. Cardenas-Rodriguez, M.; Chatzi, A.; Tokatlidis, K. Iron-sulfur Clusters: From Metals through Mitochondria Biogenesis to Disease. J. Biol. Inorg. Chem. 2018, 23, 509-520. [CrossRef]

75. Shimomura, Y.; Takahashi, Y.; Kakuta, Y.; Fukuyama, K. Crystal Structure of Escherichia coli YfhJ Protein, a Member of the ISC Machinery Involved in Assembly of Iron-sulfur Clusters. Proteins 2005, 60, 566-569. [CrossRef] [PubMed]

76. Schwartz, C.J.; Djaman, O.; Imlay, J.A.; Kiley, P.J. The Cysteine Desulfurase, IscS, has a Major Role in in vivo Fe-S Cluster Formation in Escherichia coli. Proc. Natl. Acad. Sci. USA 2000, 97, 9009-9014. [CrossRef]

77. Mettert, E.L.; Kiley, P.J. Fe-S Proteins that Regulate Gene Expression. BBA Mol. Cell Res. 2015, 1853, 1284-1293. [CrossRef] [PubMed]

78. Saini, V.; Farhana, A.; Glasgow, J.N.; Steyn, A.J.C. Iron-sulfur Cluster Proteins and Microbial Regulation: Implications for Understanding Tuberculosis. Curr. Opin. Chem. Biol. 2012, 16, 45-53. [CrossRef] [PubMed]

79. Takahashi, Y.; Tokumoto, U. A Third Bacterial System for the Assembly of Iron-sulfur Clusters with Homologs in Archaea and Plastids. J. Biol. Chem. 2002, 277, 28380-28383. [CrossRef]

80. Zheng, C.; Black, K.A.; Santos, P.C.D. Diverse Mechanisms of Sulfur Decoration in Bacterial tRNA and their Cellular Functions. Biomolecules 2017, 7, 33. [CrossRef]

81. Čavužić, M.; Liu, Y. Biosynthesis of Sulfur-Containing tRNA Modifications: A Comparison of Bacterial, Archaeal, and Eukaryotic Pathways. Biomolecules 2017, 7, 27. [CrossRef]

82. Lauhon, C.T. Requirement for IscS in Biosynthesis of All Thionucleosides in Escherichia coli. J. Bacteriol. 2002, 184, 6820. [CrossRef]

83. Landgraf, B.J.; Arcinas, A.J.; Lee, K.H.; Booker, S.J. Identification of an Intermediate Methyl Carrier in the Radical SAdenosylmethionine Methylthiotransferases RimO and MiaB. J. Am. Chem. Soc. 2013, 135, 15404-15416. [CrossRef] [PubMed]

84. Maiocco, S.J.; Arcinas, A.J.; Landgraf, B.J.; Lee, K.H.; Booker, S.J.; Elliott, S.J. Transformations of the FeS Clusters of the Methylthiotransferases MiaB and RimO, Detected by Direct Electrochemistry. Biochemistry 2016, 55, 5531-5536. [CrossRef] [PubMed]

85. Hernández, H.L.; Pierrel, F.; Elleingand, E.; García-Serres, R.; Huynh, B.H.; Johnson, M.K.; Fontecave, M.; Atta, M. MiaB, a Bifunctional Radical-S-Adenosylmethionine Enzyme Involved in the Thiolation and Methylation of tRNA, Contains Two Essential [4Fe-4S] Clusters. Biochemistry 2007, 46, 5140-5147. [CrossRef]

86. Chionh, Y.H.; McBee, M.; Babu, I.R.; Hia, F.; Lin, W.; Zhao, W.; Cao, J.; Dziergowska, A.; Malkiewicz, A.; Begley, T.J.; et al. tRNA-mediated Codon-biased Translation in Mycobacterial Hypoxic Persistence. Nat. Commun. 2016, 7, 13302. [CrossRef] [PubMed]

87. Black, K.A.; Santos, P.C.D. Abbreviated Pathway for Biosynthesis of 2-Thiouridine in Bacillus subtilis. J. Bacteriol. 2015, 197, 1952-1962. [CrossRef] [PubMed]

88. Kambampati, R.; Lauhon, C.T. Evidence for the Transfer of Sulfane Sulfur from IscS to ThiI during the in Vitro Biosynthesis of 4-Thiouridine in Escherichia coli tRNA. J. Biol. Chem. 2000, 275, 10727-10730. [CrossRef] [PubMed]

89. Numata, T.; Ikeuchi, Y.; Fukai, S.; Suzuki, T.; Nureki, O. Snapshots of tRNA Sulphuration via an Adenylated Intermediate. Nature 2006, 442, 419-424. [CrossRef]

90. Palenchar, P.M.; Buck, C.J.; Cheng, H.; Larson, T.J.; Mueller, E.G. Evidence that ThiI, an Enzyme Shared Between Thiamin and 4-Thiouridine Biosynthesis, may be a Sulfurtransferase that Proceeds through a Persulfide Intermediate. J. Biol. Chem. 2000, 275, 8283-8286. [CrossRef] 
91. Mueller, E.G.; Palenchar, P.M.; Buck, C.J. The Role of the Cysteine Residues of Thil in the Generation of 4-Thiouridine in tRNA. J. Biol. Chem. 2001, 276, 33588-33595. [CrossRef] [PubMed]

92. Jäger, G.; Leipuviene, R.; Pollard, M.G.; Qian, Q.; Björk, G.R. The Conserved Cys-X1-X2-Cys Motif Present in the TtcA Protein Is Required for the Thiolation of Cytidine in Position 32 of tRNA from Salmonella enterica Serovar Typhimurium. J. Bacteriol. 2004, 186, 750. [CrossRef]

93. Leipuviene, R.; Qian, Q.; Björk, G.R. Formation of Thiolated Nucleosides Present in tRNA from Salmonella enterica Serovar Typhimurium Occurs in Two Principally Distinct Pathways. J. Bacteriol. 2004, 186, 758-766. [CrossRef] [PubMed]

94. Mihara, H.; Hidese, R.; Yamane, M.; Kurihara, T.; Esaki, N. The iscS Gene Deficiency Affects the Expression of Pyrimidine Metabolism Genes. Biochem. Biophys. Res. 2008, 372, 407-411. [CrossRef] [PubMed]

95. Lacourciere, G.M. Selenium Is Mobilized In Vivo from Free Selenocysteine and is Incorporated Specifically into Formate Dehydrogenase H and tRNA Nucleosides. J. Bacteriol. 2002, 184, 1940-1946. [CrossRef] [PubMed]

96. Mihara, H.; Kato, S.; Lacourciere, G.M.; Stadtman, T.C.; Kennedy, R.A.; Kurihara, T.; Tokumoto, U.; Takahashi, Y.; Esaki, N. The iscS Gene is Essential for the Biosynthesis of 2-Selenouridine in tRNA and the Selenocysteine-containing Formate Dehydrogenase H. Proc. Natl. Acad. Sci. USA 2002, 99, 6679-6683. [CrossRef] [PubMed]

97. Cronan, J.E. Assembly of Lipoic Acid on its Cognate Enzymes: An Extraordinary and Essential Biosynthetic Pathway. Microbiol. Mol. Biol. Rev. 2016, 80, 429. [CrossRef]

98. Spalding, M.D.; Prigge, S.T. Lipoic Acid Metabolism in Microbial Pathogens. Microbiol. Mol. Biol. Rev. 2010, 74, 200-228. [CrossRef]

99. Solmonson, A.; DeBerardinis, R.J. Lipoic Acid Metabolism and Mitochondrial Redox Regulation. J. Biol. Chem. 2018, 293, 7522-7530. [CrossRef]

100. Cronan, J.E. Biotin and Lipoic Acid: Synthesis, Attachment, and Regulation. EcoSal Plus 2013, 6. [CrossRef]

101. Cicchillo, R.M.; Booker, S.J. Mechanistic Investigations of Lipoic Acid Biosynthesis in Escherichia coli: Both Sulfur Atoms in Lipoic Acid are Contributed by the same Lipoyl Synthase Polypeptide. J. Am. Chem. Soc. 2005, 127, 2860-2861. [CrossRef]

102. McCarthy, E.L.; Booker, S.J. Destruction and Reformation of an Iron-Sulfur Cluster during Catalysis by Lipoyl Synthase. Science 2017, 358, 373-377. [CrossRef]

103. Kriek, M.; Peters, L.; Takahashi, Y.; Roach, P.L. Effect of Iron-Sulfur Cluster Assembly Proteins on the Expression of Escherichia coli Lipoic Acid Synthase. Protein Expr. Purif. 2003, 28, 241-245. [CrossRef]

104. Reed, L.J. From Lipoic Acid to Multi-enzyme Complexes. Protein Sci. 1998, 7, 220-224. [CrossRef] [PubMed]

105. Ma, Q.; Zhao, X.; Eddine, A.N.; Geerlof, A.; Li, X.; Cronan, J.E.; Kaufmann, S.H.; Wilmanns, M. The Mycobacterium tuberculosis LipB Enzyme Functions as a Cysteine/Lysine Dyad Acyltransferase. Proc. Natl. Acad. Sci. USA 2006, 103, 8662-8667. [CrossRef]

106. Shi, S.; Ehrt, S. Dihydrolipoamide Acyltransferase is Critical for Mycobacterium tuberculosis Pathogenesis. Infect. Immun. 2006, 74, 56-63. [CrossRef] [PubMed]

107. Bryk, R.; Gold, B.; Venugopal, A.; Singh, J.; Samy, R.; Pupek, K.; Cao, H.; Popescu, C.; Gurney, M.; Hotha, S.; et al. Selective Killing of Nonreplicating Mycobacteria. Cell Host Microbe 2008, 3, 137-145. [CrossRef]

108. Venugopal, A.; Bryk, R.; Shi, S.; Rhee, K.; Rath, P.; Schnappinger, D.; Ehrt, S.; Nathan, C. Virulence of Mycobacterium tuberculosis Depends on Lipoamide Dehydrogenase, a Member of Three Multienzyme Complexes. Cell Host Microbe 2011, 9, 21-31. [CrossRef]

109. Salaemae, W.; Booker, G.W.; Polyak, S.W. The Role of Biotin in Bacterial Physiology and Virulence: A Novel Antibiotic Target for Mycobacterium tuberculosis. Microbiol. Spectr. 2016, 4, 1-20. [CrossRef]

110. Gande, R.; Gibson, K.J.; Brown, A.K.; Krumbach, K.; Dover, L.G.; Sahm, H.; Shioyama, S.; Oikawa, T.; Besra, G.S.; Eggeling, L. Acyl-CoA Carboxylases (accD2 and accD3), Together with a Unique Polyketide Synthase (Cg-pks), are Key to Mycolic Acid Biosynthesis in Corynebacterianeae such as Corynebacterium glutamicum and Mycobacterium tuberculosis. J. Biol. Chem. 2004, 279, 44847-44857. [CrossRef]

111. Ehrt, S.; Schnappinger, D. Mycobacterium tuberculosis Virulence: Lipids Inside and Out. Nat. Med. 2007, 13, 284-285. [CrossRef]

112. Marquet, A.; Bui, B.T.S.; Florentin, D. Biosynthesis of Biotin and Lipoic Acid. In Vitamins and Hormones; Academic Press Inc.: Cambridge, MA, USA, 2001; Volume 61, pp. 51-101. [CrossRef]

113. Lotierzo, M.; Bui, B.T.S.; Florentin, D.; Escalettes, F.; Marquet, A. Biotin Synthase Mechanism: An overview. Biochem. Soc. Trans. 2005, 33, 820-823. [CrossRef]

114. Dey, S.; Lane, J.M.; Lee, R.E.; Rubin, E.J.; Sacchettini, J.C. Structural Characterization of the Mycobacterium tuberculosis Biotin Biosynthesis Enzymes 7,8-diaminopelargonic acid Synthase and Dethiobiotin Synthetase. Biochemistry 2010, 49, 6746-6760. [CrossRef] [PubMed]

115. Lin, S.; Cronan, J.E. Closing in on Complete Pathways of Biotin Biosynthesis. Mol. Biosyst. 2011, 7, 1811-1821. [CrossRef] [PubMed]

116. Begley, T.P.; Xi, J.; Kinsland, C.; Taylor, S.; McLafferty, F. The Enzymology of Sulfur Activation during Thiamin and Biotin Biosynthesis. Curr. Opin. Chem. Biol. 1999, 3, 623-629. [CrossRef]

117. Ollagnier-de-Choudens, S.; Mulliez, E.; Hewitson, K.S.; Fontecave, M. Biotin Synthase is a Pyridoxal Phosphate-Dependent Cysteine Desulfurase. Biochemistry 2002, 41, 9145-9152. [CrossRef] [PubMed]

118. Abdel-Hamid, A.M.; Cronan, J.E. In Vivo Resolution of Conflicting in Vitro Results: Synthesis of Biotin from Dethiobiotin does not Require Pyridoxal Phosphate. Chem. Biol. 2007, 14, 1215-1220. [CrossRef] 
119. Kiyasu, T.; Asakura, A.; Nagahashi, Y.; Hoshino, T. Contribution of Cysteine Desulfurase (NifS protein) to the Biotin Synthase Reaction of Escherichia coli. J. Bacteriol. 2000, 182, 2879-2885. [CrossRef]

120. Tiwari, D.; Park, S.W.; Essawy, M.M.; Dawadi, S.; Mason, A.; Nandakumar, M.; Zimmerman, M.; Mina, M.; Ho, H.P.; Engelhart, C.A.; et al. Targeting Protein Biotinylation Enhances Tuberculosis Chemotherapy. Sci. Transl. Med. 2018, 10. [CrossRef]

121. Lonsdale, D. A Review of the Biochemistry, Metabolism and Clinical Benefits of Thiamin(e) and its Derivatives. Evid. Based Complement. Alternat. Med. 2006, 3, 49-59. [CrossRef]

122. Begley, T.P.; Downs, D.M.; Ealick, S.E.; McLafferty, F.W.; Van Loon, A.P.; Taylor, S.; Campobasso, N.; Chiu, H.J.; Kinsland, C.; Reddick, J.J.; et al. Thiamin Biosynthesis in Prokaryotes. Arch. Microbiol. 1999, 171, 293-300. [CrossRef]

123. Kriek, M.; Martins, F.; Leonardi, R.; Fairhurst, S.A.; Lowe, D.J.; Roach, P.L. Thiazole Synthase from Escherichia coli: An Investigation of the Substrates and Purified Proteins Required for Activity In Vitro. J. Biol. Chem. 2007, 282, 17413-17423. [CrossRef]

124. Ealick, S.E.; Jurgenson, C.T.; Begley, T.P. Biosynthesis of Thiamin Pyrophosphate. EcoSal Plus 2009, 3, 1-16. [CrossRef]

125. Taylor, S.V.; Kelleher, N.L.; Kinsland, C.; Chiu, H.J.; Costello, C.A.; Backstrom, A.D.; McLafferty, F.W.; Begley, T.P. Thiamin Biosynthesis in Escherichia coli: Identification of this Thiocarboxylate as the Immediate Sulfur Donor in the Thiazole Formation. J. Biol. Chem. 1998, 273, 16555-16560. [CrossRef] [PubMed]

126. Tokumoto, U.; Takahashi, Y. Genetic Analysis of the isc Operon in Escherichia coli Involved in the Biogenesis of Cellular Iron-Sulfur Proteins1. J. Biochem. 2001, 130, 63-71. [CrossRef] [PubMed]

127. Skovran, E.; Downs, D.M. Metabolic Defects Caused by Mutations in the Isc Gene Cluster in Salmonella enterica Serovar Typhimurium: Implications for Thiamine Synthesis. J. Bacteriol. 2000, 182, 3896-3903. [CrossRef] [PubMed]

128. Lauhon, C.T.; Kambampati, R. The IscS Gene in Escherichia coli is Required for the Biosynthesis of 4- Thiouridine, Thiamin, and NAD. J. Biol. Chem. 2000, 275, 20096-20103. [CrossRef]

129. Leimkühler, S.; Wuebbens, M.M.; Rajagopalan, K.V. The History of the Discovery of the Molybdenum Cofactor and Novel Aspects of its Biosynthesis in Bacteria. Coord. Chem. Rev. 2011, 255, 1129-1144. [CrossRef]

130. Hille, R.; Hall, J.; Basu, P. The Mononuclear Molybdenum Enzymes. Chem. Rev. 2014, 114, 3963-4038. [CrossRef]

131. Romão, M.J.; Knäblein, J.; Huber, R.; Moura, J.J. Structure and Function of Molybdopterin Containing Enzymes. Prog. Biophys. Mol. Biol. 1997, 68, 121-144. [CrossRef]

132. Yokoyama, K.; Leimkühler, S. The Role of FeS Clusters for Molybdenum Cofactor Biosynthesis and Molybdoenzymes in Bacteria. Biochim. Biophys. Acta Mol. Cell Res. 2015, 1853, 1335-1349. [CrossRef]

133. Zhang, W.; Urban, A.; Mihara, H.; Leimkühler, S.; Kurihara, T.; Esaki, N. IscS Functions as a Primary Sulfur-donating Enzyme by Interacting Specifically with MoeB and MoaD in the Biosynthesis of Molybdopterin in Escherichia coli. J. Biol. Chem. 2010, 285, 2302-2308. [CrossRef]

134. Kabil, O.; Banerjee, R. Redox Biochemistry of Hydrogen Sulfide. J. Biol. Chem. 2010, 285, 21903-21907. [CrossRef] [PubMed]

135. Kabil, O.; Banerjee, R. Enzymology of H2S Biogenesis, Decay and Signaling. Antioxid. Redox Signal. 2014, 20, 770-782. [CrossRef] [PubMed]

136. Kimura, H. Production and Physiological Effects of Hydrogen Sulfide. Antioxid. Redox Signal. 2014, 20, 783-793. [CrossRef] [PubMed]

137. Pal, V.K.; Bandyopadhyay, P.; Singh, A. Hydrogen Sulfide in Physiology and Pathogenesis of Bacteria and Viruses. IUBMB Life 2018, 70, 393-410. [CrossRef]

138. Wang, J.; Guo, X.; Li, H.; Qi, H.; Qian, J.; Yan, S.; Shi, J.; Niu, W. Hydrogen Sulfide from Cysteine Desulfurase, not 3Mercaptopyruvate Sulfurtransferase, Contributes to Sustaining Cell Growth and Bioenergetics in E. coli under Anaerobic Conditions. Front. Microbiol. 2019, 10, 2357. [CrossRef]

139. Großhennig, S.; Ischebeck, T.; Gibhardt, J.; Busse, J. Hydrogen Sulfide is a Novel Potential Virulence Factor of Mycoplasma pneumoniae: Characterization of the Unusual Cysteine Desulfurase/Desulfhydrase HapE. Mol. Microbiol. 2016, 100, 42-54. [CrossRef]

140. Wang, L.; Jiang, S.; Deng, Z.; Dedon, P.C.; Chen, S. DNA Phosphorothioate Modification-A New Multi-Functional Epigenetic System in Bacteria. FEMS Microbiol. Rev. 2019, 43, 109-122. [CrossRef]

141. Liu, L.; Jiang, S.; Xing, M.; Chen, C.; Lai, C.; Li, N.; Liu, G.; Wu, D.; Gao, H.; Hong, L.; et al. Structural Analysis of an 1-Cysteine Desulfurase from an Ssp DNA Phosphorothioation System. mBio 2020, 11. [CrossRef]

142. Tong, T.; Chen, S.; Wang, L.; Tang, Y.; Ryu, J.Y.; Jiang, S.; Wu, X.; Chen, C.; Luo, J.; Deng, Z.; et al. Occurrence, Evolution, and Functions of DNA Phosphorothioate Epigenetics in Bacteria. Proc. Natl. Acad. Sci. USA 2018, 115, E2988-E2996. [CrossRef]

143. Dai, D.; Du, A.; Xiong, K.; Pu, T.; Zhou, X.; Deng, Z.; Liang, J.; He, X.; Wang, Z. DNA Phosphorothioate Modification Plays a role in Peroxides Resistance in Streptomyces lividans. Front. Microbiol. 2016, 7, 1380. [CrossRef]

144. Yang, Y.; Xu, G.; Liang, J.; He, Y.; Xiong, L.; Li, H.; Bartlett, D.; Deng, Z.; Wang, Z.; Xiao, X. DNA Backbone Sulfur-Modification Expands Microbial Growth Range under Multiple Stresses by its Anti-oxidation Function. Sci. Rep. 2017, 7, 3516. [CrossRef] [PubMed]

145. Outten, F.W.; Djaman, O.; Storz, G. A suf Operon Requirement for Fe-S Cluster Assembly during Iron Starvation in Escherichia coli. Mol. Microbiol. 2004, 52, 861-872. [CrossRef] [PubMed]

146. Lee, K.C.; Yeo, W.S.; Roe, J.H. Oxidant-responsive Induction of the suf Operon, Encoding a Fe-S Assembly System, through Fur and IscR in Escherichia coli. J. Bacteriol. 2008, 190, 8244-8247. [CrossRef] [PubMed] 
147. Lee, J.H.; Yeo, W.S.; Roe, J.H. Induction of the sufA Operon Encoding Fe-S Assembly Proteins by Superoxide Generators and Hydrogen Peroxide: Involvement of OxyR, IHF and an Unidentified Oxidant-responsive Factor. Mol. Microbiol. 2004, 51, 1745-1755. [CrossRef] [PubMed]

148. Miller, H.K.; Kwuan, L.; Schwiesow, L.; Bernick, D.L.; Mettert, E.; Ramirez, H.A.; Ragle, J.M.; Chan, P.P.; Kiley, P.J.; Lowe, T.M.; et al. IscR Is Essential for Yersinia pseudotuberculosis Type III Secretion and Virulence. PLoS Pathog. 2014, 10, e1004194. [CrossRef]

149. Lim, J.G.; Choi, S.H. IscR is a Global Regulator Essential for Pathogenesis of Vibrio vulnificus and Induced by Host Cells. Infect. Immun. 2014, 82, 569-578. [CrossRef]

150. Santos, J.A.; Pereira, P.J.B.; Macedo-Ribeiro, S. What a Difference a Cluster Makes: The Multifaceted Roles of IscR in Gene Regulation and DNA Recognition. Biochim. Biophys. Acta Proteins Proteom. 2015, 1854, 1101-1112. [CrossRef]

151. Schwartz, C.J.; Giel, J.L.; Patschkowski, T.; Luther, C.; Ruzicka, F.J.; Beinert, H.; Kiley, P.J. IscR, An Fe-S Clustercontaining Transcription Factor, Represses Expression of Escherichia coli Genes Encoding Fe-S Cluster Assembly Proteins. Proc. Natl. Acad. Sci. USA 2001, 98, 14895-14900. [CrossRef]

152. Giel, J.L.; Rodionov, D.; Liu, M.; Blattner, F.R.; Kiley, P.J. IscR-dependent Gene Expression links Iron-Sulphur Cluster Assembly to the Control of O2-regulated Genes in Escherichia coli. Mol. Microbiol. 2006, 60, 1058-1075. [CrossRef]

153. Yeo, W.S.; Lee, J.H.; Lee, K.C.; Roe, J.H. IscR Acts as an Activator in Response to Oxidative Stress for the suf Operon Encoding Fe-S Assembly Proteins. Mol. Microbiol. 2006, 61, 206-218. [CrossRef]

154. Wang, T.; Shen, G.; Balasubramanian, R.; McIntosh, L.; Bryant, D.A.; Golbeck, J.H. The sufR Gene (sll0088 in Synechocystis sp. Strain PCC 6803) Functions as a Repressor of the sufBCDS Operon in Iron-Sulfur Cluster Biogenesis in Cyanobacteria. J. Bacteriol. 2004, 186, 956-967. [CrossRef] [PubMed]

155. Balasubramanian, R.; Shen, G.; Bryant, D.A.; Golbeck, J.H. Regulatory Roles for IscA and SufA in Iron Homeostasis and Redox Stress Responses in the Cyanobacterium Synechococcus sp. Strain PCC 7002. J. Bacteriol. 2006, 188, 3182-3191. [CrossRef] [PubMed]

156. Shen, G.; Balasubramanian, R.; Wang, T.; Wu, Y.; Hoffart, L.M.; Krebs, C.; Bryant, D.A.; Golbeck, J.H. SufR Coordinates Two $[4 \mathrm{Fe}-4 \mathrm{~S}]^{2+, 1+}$ Clusters and Functions as a Transcriptional Repressor of the sufBCDS Operon and an Autoregulator of sufR in Cyanobacteria. J. Biol. Chem. 2007, 282, 31909-31919. [CrossRef]

157. Cortes, T.; Schubert, O.T.; Rose, G.; Arnvig, K.B.; Comas, I.; Aebersold, R.; Young, D.B. Genome-wide Mapping of Transcriptional Start Sites Defines an Extensive Leaderless Transcriptome in Mycobacterium tuberculosis. Cell Rep. 2013, 5, 1121-1131. [CrossRef] [PubMed]

158. Massé, E.; Vanderpool, C.K.; Gottesman, S. Effect of RyhB small RNA on Global Iron use in Escherichia coli. J. Bacteriol. 2005, 187, 6962-6971. [CrossRef]

159. Desnoyers, G.; Morissette, A.; Prévost, K.; Massé, E. Small RNA-induced Differential Degradation of the Polycistronic mRNA iscRSUA. EMBO J. 2009, 28, 1551-1561. [CrossRef]

160. Riboldi, G.P.; de Oliveira, J.S.; Frazzon, J. Enterococcus faecalis SufU Scaffold Protein Enhances SufS Desulfurase Activity by Acquiring Sulfur from its Cysteine-153. Biochim. Biophys. Acta Proteins Proteom. 2011, 1814, 1910-1918. [CrossRef]

161. Albrecht, A.G.; Netz, D.J.; Miethke, M.; Pierik, A.J.; Burghaus, O.; Peuckert, F.; Lill, R.; Marahiel, M.A. SufU is an Essential Iron-Sulfur Cluster Scaffold Protein in Bacillus subtilis. J. Bacteriol. 2010, 192, 1643-1651. [CrossRef]

162. Shan, Y.; Napoli, E.; Cortopassi, G. Mitochondrial Frataxin Interacts with ISD11 of the NFS1/ISCU Complex and Multiple Mitochondrial Chaperones. Hum. Mol. Genet. 2007, 16, 929-941. [CrossRef]

163. Adinolfi, S.; Iannuzzi, C.; Prischi, F.; Pastore, C.; Iametti, S.; Martin, S.R.; Bonomi, F.; Pastore, A. Bacterial Frataxin CyaY is the Gatekeeper of Iron-Sulfur Cluster Formation Catalyzed by IscS. Nat. Struct. Mol. Biol. 2009, 16, 390-396. [CrossRef]

164. Yoon, T.; Cowan, J.A. Iron-Sulfur Cluster Biosynthesis. Characterization of Frataxin as an Iron Donor for Assembly of [2Fe-2S] Clusters in ISU-type Proteins. J. Am. Chem. Soc. 2003, 125, 20, 6078-84. [CrossRef]

165. Layer, G.; Ollagnier-de-Choudens, S.; Sanakis, Y.; Fontecave, M. Iron-Sulfur Cluster Biosynthesis: Characterization of Escherichia coli CyaY as an Iron Donor for the Assembly of [2Fe-2S] Clusters in the Scaffold IscU. J. Biol. Chem. 2003, 281, 16256-16263. [CrossRef]

166. Li, D.S.; Ohshima, K.; Jiralerspong, S.; Bojanowski, M.W.; Pandolfo, M. Knock-out of the cyaY Gene in Escherichia coli does not Affect Cellular Iron Content and Sensitivity to Oxidants. FEBS Lett. 1999, 456, 13-16. [CrossRef]

167. Vivas, E.; Skovran, E.; Downs, D.M. Salmonella enterica Strains Lacking the Frataxin Homolog CyaY Show Defects in Fe-S Cluster Metabolism in Vivo. J. Bacteriol. 2006, 188, 1175-1179. [CrossRef]

168. Velayudhan, J.; Karlinsey, J.E.; Frawley, E.R.; Becker, L.A.; Nartea, M.; Fang, F.C. Distinct Roles of the Salmonella enterica Serovar Typhimurium CyaY and YggX Proteins in the Biosynthesis and Repair of Iron-Sulfur Clusters. Infect. Immun. 2014, 82, 1390-1401. [CrossRef] [PubMed]

169. Kim, J.H.; Frederick, R.O.; Reinen, N.M.; Troupis, A.T.; Markley, J.L. [2Fe-2S]-Ferredoxin Binds Directly to Cysteine Desulfurase and Supplies an Electron for Iron-Sulfur Cluster Assembly but is Displaced by the Scaffold Protein or Bacterial Frataxin. J. Am. Chem. Soc. 2013, 135, 8117-8120. [CrossRef] [PubMed]

170. Zheng, C.; Guo, S.; Tennant, W.G.; Pradhan, P.K.; Black, K.A.; Santos, P.C.D. The Thioredoxin System Reduces Protein Persulfide Intermediates Formed during the Synthesis of Thio-Cofactors in Bacillus subtilis. Biochemistry 2019, 58, 1892-1904. [CrossRef] [PubMed] 
171. Py, B.; Moreau, P.L.; Barras, F. Fe-S Clusters, Fragile Sentinels of the Cell. Curr. Opin. Microbiol. 2011, 14, 218-223. [CrossRef]

172. Touati, D. Iron and Oxidative Stress in Bacteria. Arch. Biochem. Biophys. 2000, 373, 1-6. [CrossRef] [PubMed]

173. Ezraty, B.; Vergnes, A.; Banzhaf, M.; Duverger, Y.; Huguenot, A.; Brochado, A.R.; Su, S.Y.; Espinosa, L.; Loiseau, L.; Py, B.; et al. Fe-S cluster Biosynthesis Controls Uptake of Aminoglycosides in a ROS-less Death Pathway. Science 2013, 340, $1583-1587$. [CrossRef]

174. Patel, R.; Rinker, L.; Peng, J.; Rinker, L.; Peng, J.; Chilian, M. Reactive Oxygen Species: The Good and the Bad. Intech Open 2018. [CrossRef]

175. Lanciano, P.; Khalfaoui-Hassani, B.; Selamoglu, N.; Ghelli, A.; Rugolo, M.; Daldal, F. Molecular Mechanisms of Superoxide Production by Complex III: A Bacterial versus Human Mitochondrial Comparative Case Study. Biochim. Biophys. Acta 2014, 1827, 1332-1339. [CrossRef] [PubMed]

176. Imlay, J.A. The Molecular Mechanisms and Physiological Consequences of Oxidative Stress: Lessons from a Model Bacterium. Nat. Rev. Microbiol. 2013, 11, 443-454. [CrossRef] [PubMed]

177. Moini, H.; Packer, L.; Saris, N.L. Antioxidant and Prooxidant Activities of $\alpha$-Lipoic Acid and Dihydrolipoic Acid. Toxicol. Appl. Pharmacol. 2002, 182, 84-90. [CrossRef] [PubMed]

178. Packer, L.; Witt, E.H.; Tritschler, H.J. Alpha-Lipoic Acid as a Biological Antioxidant. Free Radic. Biol. Med. 1995, 19, 227-250. [CrossRef]

179. Vertuani, S.; Angusti, A.; Manfredini, S. The Antioxidants and Pro-Antioxidants Network: An Overview. Curr. Pharm. Des. 2005, 10, 1677-1694. [CrossRef]

180. Ehrt, S.; Schnappinger, D. Mycobacterial Survival Strategies in the Phagosome: Defence Against Host Stresses. Cell Microbiol. 2009, 11, 1170-1178. [CrossRef]

181. Mehta, M.; Singh, A. Mycobacterium tuberculosis WhiB3 Maintains Redox Homeostasis and Survival in Response to Reactive Oxygen and Nitrogen species. Free Radic. Biol. Med. 2019, 131, 50-58. [CrossRef]

182. Rivera-Chávez, F.; Zhang, L.F.; Faber, F.; Lopez, C.A.; Byndloss, M.X.; Olsan, E.E.; Xu, G.; Velazquez, E.M.; Lebrilla, C.B.; Winter, S.E.; et al. Depletion of Butyrate-Producing Clostridia from the Gut Microbiota Drives an Aerobic Luminal Expansion of Salmonella. Cell Host Microbe 2016, 19, 443-454. [CrossRef]

183. Alamuri, P.; Mehta, N.; Burk, A.; Maier, R.J. Regulation of the Helicobacter pylori Fe-S Cluster Synthesis Protein NifS by Iron, Oxidative Stress Conditions, and Fur. J. Bacteriol. 2006, 188, 5325-5330. [CrossRef]

184. Dai, Y.; Outten, F.W. The E. coli SufS-SufE Sulfur Transfer System is more Resistant to Oxidative Stress than IscS-IscU. FEBS Lett. 2012, 586, 4016-4022. [CrossRef] [PubMed]

185. Shukla, P.; Khodade, V.S.; Chandra, M.S.; Chauhan, P.; Mishra, S.; Siddaramappa, S.; Pradeep, B.E.; Singh, A.; Chakrapani, H. 'On Demand' Redox Buffering by H2S Contributes to Antibiotic Resistance Revealed by a Bacteria-specific H2S Donor. Chem. Sci. 2017, 8, 4967-4972. [CrossRef] [PubMed]

186. Mishra, R.; Kohli, S.; Malhotra, N.; Bandyopadhyay, P.; Mehta, M.; Munshi, M.; Adiga, V.; Ahuja, V.K.; Shandil, R.K.; Rajmani, R.S.; et al. Targeting Redox Heterogeneity to Counteract Drug Tolerance in Replicating Mycobacterium tuberculosis. Sci. Transl. Med. 2019, 11. [CrossRef] [PubMed]

187. Fuentes, D.E.; Fuentes, E.L.; Castro, M.E.; Pérez, J.M.; Araya, M.A.; Chasteen, T.G.; Pichuantes, S.E.; Vásquez, C.C. Cysteine Metabolism-Related Genes and Bacterial Resistance to Potassium Tellurite. J. Bacteriol. 2007, 189, 8953-8960. [CrossRef]

188. Rojas, D.M.; Vásquez, C.C. Sensitivity to Potassium Tellurite of Escherichia coli Cells Deficient in CSD, CsdB and IscS Cysteine Desulfurases. Res. Microbiol. 2005, 156, 465-471. [CrossRef]

189. Lithgow, J.K.; Hayhurst, E.J.; Cohen, G.; Aharonowitz, Y.; Foster, S.J. Role of a Cysteine Synthase in Staphylococcus aureus. J. Bacteriol. 2004, 186, 1579-1590. [CrossRef]

190. Vernis, L.; el Banna, N.; Baïlle, D.; Hatem, E.; Heneman, A.; Huang, M. Fe-S Clusters Emerging as Targets of Therapeutic Drugs. Oxidative Med. Cell. Longev. 2017. [CrossRef]

191. Ling, J.; Cho, C.; Guo, L.T.; Aerni, H.R.; Rinehart, J.; Söll, D. Protein Aggregation Caused by Aminoglycoside Action Is Prevented by a Hydrogen Peroxide Scavenger. Mol. Cell. 2012, 48, 713-722. [CrossRef]

192. Wu, A.; Zhang, Y.; Zheng, C.; Dai, Y.; Liu, Y.; Zeng, J.; Gu, G.; Liu, J. Purification and Enzymatic Characteristics of Cysteine Desulfurase, IscS, in Acidithiobacillus ferrooxidans ATCC 23270. Trans. Nonferrous Met. Soc. China 2008, 18, 1450-1457. [CrossRef]

193. Charan, M.; Singh, N.; Kumar, B.; Srivastava, K.; Siddiqi, I. Sulfur Mobilization for Fe-S Cluster Assembly by the Essential SUF Pathway in the Plasmodium falciparum Apicoplast and Its Inhibition. Antimicrob. Agents Chemother. 2014, 58, 3389-3398. [CrossRef]

194. Li, Y.; Wang, F.; Wu, L.; Zhu, M.; He, G.; Chen, X.; Sun, F.; Liu, Q.; Wang, X.; Zhang, W. Cycloserine for Treatment of Multidrugresistant Tuberculosis: A Retrospective Cohort Study in China. Infect. Drug Resist. 2019, 12, 721-731. [CrossRef]

195. Evangelopoulos, D.; Prosser, G.A.; Rodgers, A.; Dagg, B.M.; Khatri, B.; Ho, M.M.; Gutierrez, M.G.; Cortes, T.; de Carvalho, L.P.S. Comparative Fitness Analysis of D-Cycloserine Resistant Mutants Reveals both Fitness-neutral and High-fitness Cost Genotypes. Nat. Commun. 2019, 10, 4177. [CrossRef]

196. Pérard, J.; Ollagnier-de-Choudens, S. Iron-sulfur Clusters Biogenesis by the SUF Machinery: Close to the Molecular Mechanism Understanding. J. Biol. Inorg. Chem. 2018, 23, 581-596. [CrossRef] [PubMed] 
197. Choby, J.E.; Mike, L.A.; Mashruwala, A.A.; Dutter, B.F.; Dunman, P.M.; Sulikowski, G.A.; Boyd, J.M.; Skaar, E.P. A Small-Molecule Inhibitor of Iron-Sulfur Cluster Assembly Uncovers a Link between Virulence Regulation and Metabolism in Staphylococcus aureus. Cell Chem. Biol. 2017, 23, 1351-1361. [CrossRef]

198. Mike, L.A.; Dutter, B.F.; Stauff, D.L.; Moore, J.L.; Vitko, N.P.; Aranmolate, O.; Kehl-Fie, T.E.; Sullivan, S.; Reid, P.R.; DuBois, J.L.; et al. Activation of Heme Biosynthesis by a Small Molecule that is Toxic to Fermenting Staphylococcus aureus. Proc. Natl. Acad. Sci. USA 2013. [CrossRef] [PubMed]

199. Ezraty, B.; Barras, F. The 'Liaisons Dangereuses' Between Iron and Antibiotics. FEMS Microbiol. Rev. 2016, 40, 418-435. [CrossRef] [PubMed] 